\title{
Idealist Origins: 1920s and Before
}

\author{
Martin Davies and Stein Helgeby
}

\section{Contents}

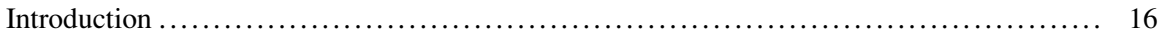

Prelude: Barzillai Quaife (1798-1873), the First Australasian Philosopher .............. 16

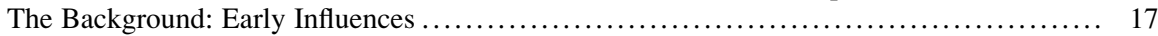

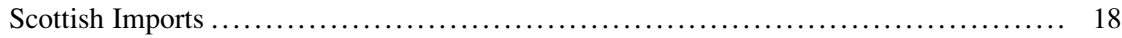

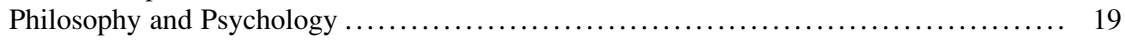

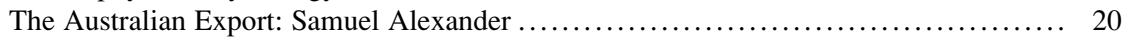

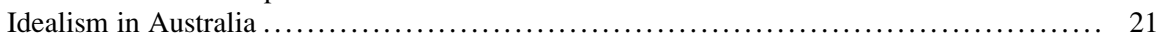

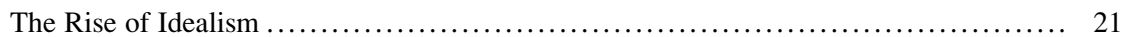

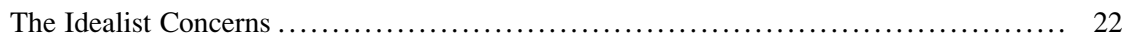

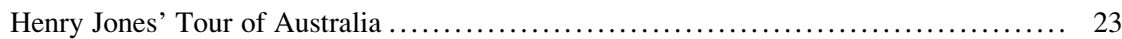

Early New Zealand Philosophy .......................................... 24

Henry Laurie (1837-1922): Australia's First Professor of Philosophy .................. 27

Laurie's Idealism ....................................................... 28

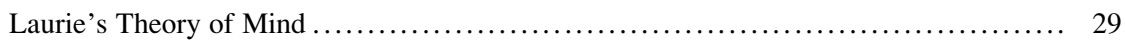

Laurie's Moral Theory ............................................... 30

Francis Anderson (1858-1941): The Christian Idealist ........................... 31

Anderson's Christian Idealism .......................................... 32

Anderson's Views of Personality and Morality .............................. 33

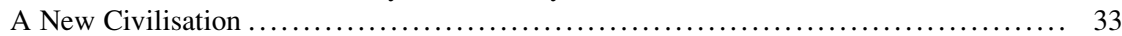

Sir William Mitchell (1861-1962): The Gifford Lecturer ............................ 34

Mitchell's Administrative Contributions and View of Education .................. 35

Mitchell's Philosophical Writing ............................................. 37

Mitchell's Philosophical Influences ...................................... 38

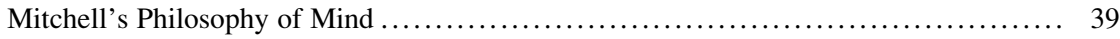

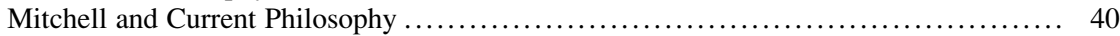

\section{Davies ( $\triangle)$}

Melbourne Graduate School of Education, The University of Melbourne, Melbourne, VIC, Australia

e-mail: wmdavies@unimelb.edu.au

\section{S. Helgeby}

Department of Finance and Deregulation, Australian Government, Canberra, ACT, Australia e-mail: Stein.Helgeby@finance.gov.au 
William Ralph Boyce Gibson (1869-1935): A Philosophy of Immediate Experience ...... 41

Gibson's Personal Idealism .............................................. 42

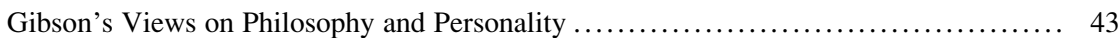

Conclusion: The Decline of Idealism $\ldots \ldots \ldots \ldots \ldots \ldots \ldots \ldots \ldots \ldots \ldots \ldots \ldots \ldots \ldots \ldots \ldots, 46$

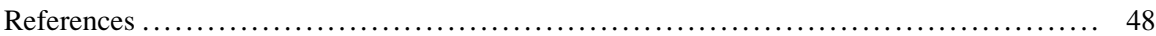

It is right and proper that Australia and New Zealand should undertake their combined share in moulding the world's thought. (Miller 1929, p. 242)

\section{Introduction}

Two approaches have dominated Western philosophy in Australia: idealism and materialism. Idealism was prevalent between the 1880s and the 1930s, but dissipated thereafter. Idealism in Australia often reflected Kantian themes, but it also reflected the revival of interest in Hegel through the work of 'absolute idealists' such as T. H. Green, F. H. Bradley, and Henry Jones. A number of the early New Zealand philosophers were also educated in the idealist tradition and were influential in their communities, but produced relatively little. In Australia, materialism gained prominence through the work of John Anderson, who arrived in Australia in 1927, and continues to be influential. John Anderson had been a student of Henry Jones, who might therefore be said to have influenced both main strands of Australian philosophical thought.

Idealism was particularly associated with the work of the first professional philosophers in Australia, such as Henry Laurie, Francis Anderson, and William Mitchell (who rejected the label), and a second generation including W. R. Boyce Gibson. In this chapter, we trace the beginnings of philosophy in Australasia, and the period of idealist dominance, mainly through these four key figures. Idealism had broad influence outside of the universities, in public and religious life (HughesWarrington and Tregenza 2008), but that is beyond the scope of this chapter. The stories of two subsequent philosophical traditions, the Wittgensteinian influence of the 1940s and 1950s, and the realism and materialism that have been the most prominent feature of Australian philosophy since the 1950s, are told in the chapters that follow.

\section{Prelude: Barzillai Quaife (1798-1873), the First Australasian Philosopher}

The honour of being the first to formally teach philosophy in Australia belongs to the Congregationalist minister Barzillai Quaife, in the 1850s, but teaching philosophy did not begin on a continuing basis until the 1880s, with the gradual establishment of universities (Grave 1984; Lockley 1967). 
Quaife was appointed by John Dunmore Lang to the Chair of Mental Philosophy and Divinity at what was called the Australian College. During his tenure, Quaife produced probably the first philosophical work to be published in the southern hemisphere: The Intellectual Sciences (Quaife 1872), a document outlining his intellectual debt to William Hamilton, James McCosh, H. L. Mansel, and Thomas Reid. This publication was based on his lectures at the Australian College between 1850 and 1851.

Like those who immediately followed him, Quaife was influenced by nineteenthcentury Scottish thought. However, his thinking was also motivated by a strong religious impulse, and his moral, ontological, and metaphysical views are coloured by notions of theistic necessity and the will of God (Grave 1984). His book has been described as an outline of psychology, metaphysics, moral philosophy, and logic in theological and anthropomorphic terms, where a conception of reality is argued which we now associate with 'the great Chain of Being' (Passmore 1963, p. 137).

Quaife was an influential and controversial newspaper editor in both Australia and New Zealand. His political approach to journalism, in the interests of Maori rights and public accountability, attracted his principal biographer (Kennett 1991). While a newspaper editor in New Zealand, Quaife's New Zealand Advertiser and Bay of Islands Gazette were suppressed for attacks on the government policies on Maori land rights_-rights which Quaife believed were being disregarded (Kennett 1991; Lockley 1967; Moon 1997). In Australia, Quaife was also noted among his local community in Paddington for decrying racism and preaching equality of men in relation to the local aboriginals (Hughenden History 2006).

After the demise of the Australian College in 1852, Quaife taught in a school, ministered to a congregation from home, and unsuccessfully attempted to resurrect his teaching career. His lack of success in obtaining an appointment may possibly be gleaned from students' view of his character: 'if teaching was his forte, omniscience was his foible' (Lockley 1967). Although he produced other works, particularly on religious themes (Quaife 1845, 1846, 1848), The Intellectual Sciences was his last major work, but it left no mark on his successors.

\section{The Background: Early Influences}

The first Australasian universities were established during the second half of the nineteenth century and grew relatively slowly. Institutionally, they represented the confidence of the colonial societies in which they were established. Intellectually, they represented both the aspiration for material progress through a highly educated social group, and the desire to engage with broader currents of European thought.

Much of the intellectual excitement of the second half of the nineteenth century attached to developments in natural science and the related fields of technology. Darwin published his Origin of Species in 1859, and evolutionary theory became prominent in a wide variety of fields, notably through the 'social Darwinism' of thinkers such as Herbert Spencer. Germ theory promised to revolutionise medical science and public health alike. Physiological discoveries of an apparently minor 
significance concerning the reflexes and the digestive system were taken to point to the redundancy of mental phenomena in explanations of mechanical and biological systems (Du Bois-Reymond 1848; Huxley 1874/1901; Passmore 1984).

Empirical psychology gained a significant impetus with the establishment of the first psychology laboratory by Wilhelm Wundt in 1879. The study of neurology advanced through the discovery of associations between parts of the brain and various memory or cognitive deficits. The empirical work of Ebbinghaus, Freud, Galton, and William James, among others, was becoming increasingly important. Such influences were carried to Australasia through emigrants, visitors, books, and journals. Major influences can be traced in the Australasian thought of the time. There were lively periodicals with an intellectual orientation, including The Victorian Review, The Melbourne Review, and The Centennial Magazine. A small number of Australasian figures, such as Alexander Sutherland, author of The Origin and Growth of the Moral Instinct, a work influenced by Darwin and Adam Smith, attracted attention overseas (Irons 1899; Sutherland 1898).

By contrast with the flourishing of natural science and technology, British philosophy is often regarded as being in decline for much of the early nineteenth century, and to have recovered only from the 1880s onwards. In 1865, David Masson located the nadir of British philosophy around 1835, but traced a gradual recovery in the succeeding 30 years (Masson 1877). A variety of empiricist and positivist philosophies predominated, with the older Scottish philosophy of common sense being perhaps the best known. Hume, the Mills, Hamilton, and, later, Spencer were highly regarded and influential. The broad field of philosophy was, however, understood to include literary figures, and particularly poets, such as Coleridge, Wordsworth, Tennyson, and Browning. Idealism was a relatively recent development in British thought. While Hamilton had been influenced by Kant, the influence of Hegel began to be felt only in the 1860s, with the publication of the first edition of James Stirling's The Secret of Hegel (1865), and the commencement of Edward Caird's teaching career at Glasgow.

\section{Scottish Imports}

Early Australasian philosophy might almost be characterised as a branch of Scottish philosophy. During the establishment of the universities of Sydney (1850), Melbourne (1853), and Adelaide (1874), the main centres of philosophy were all outposts of Scottish thought. This is not surprising given that many of the first philosophers to be given appointments were Scots. This included Francis Anderson and later John Anderson in Sydney, Henry Laurie in Melbourne, and William Mitchell in Adelaide (Grave 1984). At the oldest of the New Zealand institutions, the University of Otago (1871), the same tendencies prevailed, with the appointments of a succession of Scots, Duncan MacGregor, William Salmond, and Francis Dunlop (Pigden 2007). Elsewhere in New Zealand, highlander Hugh Mackenzie was appointed at Victoria University (founded 1899), and John Anderson's brother, William, was appointed to the University of Auckland (founded 1883) (Ardley 1982). 
English backgrounds, and sometimes an Australian education, could also be found among those who wrote on or taught philosophical themes, including John Woolley, Charles Badham, and Bernard Muscio in Sydney, and M. H. Irving, H. A. Strong, W. E. Hearn, Richard Hodgson, and W. R. Boyce Gibson in Melbourne. Such backgrounds could also be found elsewhere, including R. L. Dunbabin in Tasmania (established 1890), George Elton Mayo (educated by Mitchell in Adelaide) in Queensland (established 1909), and P. R. Le Couteur in Western Australia (established 1911). Nevertheless, among the more influential professional philosophers, it was the Scots who predominated. While the Scottish influence is now well understood in relation to Sydney, particularly through the writings and influence of John Anderson (Anderson et al. 1962, 1980, 1982; Baker 1979, 1986; Coombs 1996; Franklin 2003; Kennedy 1995; Mackie 1962; Stove, 1977), little attention has been paid to other Scottish intellectuals and traditions that were influential in Australasia.

Regardless of their background, philosophers in Australasia were constrained by their relative isolation and broad range of responsibilities. The early Australasian philosophers taught across very wide fields. Francis Anderson was to teach 'Ancient Thought, Modern Philosophy, Ethics and Sociology, Metaphysics, Logic, Psychology, Politics, and Economics'. Mitchell said his Chair was more like a sofa, since it was to cover Philosophy, Economics, Literature, Education, and Psychology (Smart 1962). At Auckland University, the prodigiously talented J. P Grossman was engaged to teach Commerce, Economics, History, Commercial Geography, and Mental Science and followed this by publishing papers on topics as diverse as afforestation, bimetallism, and proportional representation. In addition, he coached the rugby team! (Ardley 1982, p. 12) At Otago, MacGregor had both medical and philosophical training and was noted as a surgeon in Dunedin, before later becoming Inspector of Lunatic Asylums.

Establishing a community among philosophers in Australia was no easy matter. As Edmund Morris Miller (1881-1964), an idealist philosopher, psychologist, administrator, and literary scholar, noted in 1929, there were 'no strong or concentrated bonds of communion or corporate life between the thinkers and scholastic workers' in Australia (Miller 1929, p. 242). Conditions in New Zealand were perhaps even more difficult, which may have contributed to the lack of a recognisable philosophical school to parallel the materialism inaugurated by John Anderson in Australia.

\section{Philosophy and Psychology}

Throughout the nineteenth and early twentieth centuries, philosophy was conceived in relation to psychology, and particularly in terms of how they should be distinguished from each other. The Australasian Journal of Psychology and Philosophy published articles in each field, dropping the term psychology from its masthead only in 1946. 
Many of the philosophers of the time wrote on psychology, and not solely among the idealists. Laurie, Mitchell, and Boyce Gibson saw philosophical psychology as a key introduction to metaphysics. M. Scott Fletcher, Professor at the University of Queensland from 1923 to 1938, wrote on The Psychology of the New Testament (Fletcher 1912). Elton Mayo in Queensland (1919-1923) and Bernard Muscio in Sydney pursued industrial psychology, although Mayo left Australia and established his significant reputation overseas. Morris Miller in Hobart undertook psychological work that influenced public policy. W. M. Kyle, who followed Scott Fletcher in Queensland from 1938 to 1961, worked for the Army psychological services during the Second World War (Gregory 1987, pp. 72-76). J. McKellar Stewart (1878-1953) in Adelaide wrote on the unconscious and the relationship between psychology and ethics (McKellar Stewart 1923, 1926). In New Zealand, psychology was also topical with C. F. Salmond publishing a paper on 'Psychological Literature and Human Nature' (Salmond 1930) and T. A. Hunter beginning the first experimental psychology laboratory. Francis Anderson stands out from this group because of the relative lack of attention he paid to psychology.

Among the idealists, while there was considerable interest in empirical psychology conducted in the laboratory, there was an important distinction to be made between such psychology, allied to natural science, and the philosophical psychology that served as a path into broader, metaphysical, thought. This psychology was characterised, in the work of Laurie and W. R. Boyce Gibson, by a focus on the method and results of introspection and conceptual clarification. It served to establish key philosophical themes, including the relationship of mind and matter, and the status of the 'self' or personality.

\section{The Australian Export: Samuel Alexander}

The early period in Australasian intellectual life produced at least one outstanding and notable thinker-Samuel Alexander (1859-1938). Alexander was born in Sydney, educated at the University of Melbourne, and left Australian shores in 1877 bound for Oxford. He eventually became Professor at the University of Manchester where he remained, never returning to his homeland. Alexander's main work, Space, Time and Deity, delivered as Gifford Lectures in 1916-1918, was a landmark and highly influential in the 1920s and 1930s (Alexander 1920). Alexander was unusual in his presentation of a wide ranging metaphysic, in the garb of realism. It had the hallmarks of Scottish idealism and absolute idealists such as Bradley and Bosanquet, but also presented an interesting form of what became known as 'new realism'. Alexander was a venerated figure and influenced realists as well as many who have been broadly labelled idealists, such as R. G. Collingwood.

In Australia, Alexander was a major inspiration for John Anderson, who lectured repeatedly on aspects of Space, Time and Deity, particularly its treatment of categories such as identity, universality, and quality. Anderson developed his own realist metaphysics through these lectures (Anderson 2005, 2007). For quite 
different reasons, Alexander also attracted Alexander Boyce Gibson-son and successor to W. R. Boyce Gibson. For A. Boyce Gibson, Alexander was important because he placed the importance of 'constructive metaphysics' ahead of epistemology. Alexander exemplified "the "natural piety" which he preached as an antidote to the bragging anthropolatry of humanistic Idealism'. Yet his realism was 'more conciliatory and more far-reaching' than that of Moore and Russell, precisely because of his metaphysics and his search for 'the place of mind in the universe' (Boyce Gibson 1938, pp. 251-252).

Alexander's work continues to find defenders. One such defender claims that his work has been widely misinterpreted and that it offers 'a highly original version of physicalism under which higher level properties are realised by combinations of lower level properties and relations but where those higher level properties are nonetheless causally efficacious' (Gillett 2006, pp. 262-263). This continued reinterpretation of Alexander's metaphysic of emergence suggests an inherent attractiveness in the ambiguity of what might be called the pursuit of idealist concerns in a realist form. As we shall see, similar ambiguities can be found in a number of the Australasian idealists.

\section{Idealism in Australia}

\section{The Rise of Idealism}

Writing in 1929 and reflecting on nearly 50 years of academic philosophy in Australia, Morris Miller noted the strength of idealism in Australia. He remarked on the conjunction in Australia of an idealist philosophy with a highly practical and pragmatic worldview. Other philosophies were present, but they were not strong enough to result in any great contest between key ideas. Idealism was particularly associated with dynamism in ideas and in nation building. Miller commented:

It is not desired, by any means, to leave the impression that naturalism or materialism in philosophy is inimical to national advancement or springs from immaturity or decadence. But it has never stood alone in the forefront of philosophical development; and where it has appeared to do so, it has rather been as a foil to idealism than as a power of independent standing. Behind it there ever lurks a background of idealistic presuppositions. (Miller 1929, p. 246).

Idealism had become the leading tendency in Australian philosophy because it was a dynamic and resurgent element within British philosophy. Australian philosophers sought to engage with exciting and influential ideas found in the work of Edward Caird, the Scot Andrew Seth Pringle-Pattison, and T. H. Green. Idealism was also dominant because the first generation of Australian philosophers was relatively long serving. Laurie retired in 1911, to be replaced by the personal idealist W. R. Boyce Gibson, while Francis Anderson retired in 1921. Mitchell, who died in 1962 at the age of 101, was Professor of Philosophy until 1922, and Vice Chancellor, then Chancellor at the University of Adelaide, ceasing his responsibilities only in 1948. 
A variety of strains can be found within Australian idealism. Kantian and personalist influences were most fully represented, while Hegelian tendencies were more muted. Anderson, Laurie, and Miller, for example, were chiefly influenced by Kantian idealism, with its emphasis on the a priori conditions of knowledge. W. R. Boyce Gibson represented the personalist strain and derived much of his thought in response to Descartes and to the contemporary German thinker Rudolf Eucken. Miller was similarly influenced by Eucken, as was J. McKellar Stewart, who moved from Melbourne in 1923 to replace William Mitchell. Descartes was the focus of work by A. Boyce Gibson and W. A. Merrylees (Boyce Gibson 1932; Merrylees 1934). Bergson attracted considerable attention and was the subject of a study by McKellar Stewart (1911) and interested both Boyce Gibsons (Boyce Gibson 1937; Boyce Gibson 1911-1912) ' W. R. Boyce Gibson studied with Husserl and McKellar Stewart wrote on him, although a book on his work was destroyed by fire while still in manuscript (Smart 1990). As we shall see, William Mitchell's complex variant of idealism was a curious blend of influences, including Reid, Green, Bradley, James Ward, and William James.

Selwyn Grave, in his seminal history of Australasian philosophy, partly attributed the prominence of idealism to its apparent links to orthodox Christianity, at a time when Christianity was both a key intellectual and public doctrine (Grave 1984 , p. 25). Grave cited, in particular, the work of thinkers such as W. R. Boyce Gibson as exemplifying this approach. But while idealism was clearly religious and its practitioners often practicing Christians, it is not so obvious that idealist philosophy always sat easily with Christian doctrine. Rather, idealist thought could veer towards a generalised theism, linked to Christianity, but not equivalent to it. It is telling that A. Boyce Gibson noted that he was not brought up to believe in the Christian doctrine of incarnation and that it came upon him at a later point as a momentous discovery (Boyce Gibson 1964, p. 3).

\section{The Idealist Concerns}

The forms of idealism found in Australian philosophy are best characterised as a set of concerns rather than as a single body of doctrine. Starting from consciousness, and particularly from moral activity, idealists pursued moral, metaphysical, and religious themes, underpinned by a unified account of the world. They gave appropriate acknowledgement to the development of materialist natural sciences. Typically, they accepted the findings of natural science in all areas other than those that related to self-consciousness and the activities of mind. They refused to reduce consciousness or mind to matter and made mental and moral experience central to their account of the unity of the world. The idealists took little interest in, and were often hostile to, other doctrines that have sometimes been labelled 'idealist', such as the attempt to resolve all reality into mental phenomena or the theory of perception in general.

Miller's account of Laurie's position might also be taken to summarise much of the early Australian idealist position: 
An idealism that denies external reality is no true idealism. The experience of the real is admitted. What the idealist wants to know is the nature and meaning of reality; and as to its nature and meaning there may be and is a great variety of opinions. No one in his senses doubts the existence of material objects. . . . In a like manner we know mental facts as distinct from physical facts or processes. We may speak of mental processes as internal and of physical processes as external; but neither internality nor externality is applicable to mental processes as such. They are entirely different from the physical. They are not coordinate, to use Mitchell's words with which Laurie agrees; and "their correlation does not mean identity of nature". (Miller 1930, p. 10).

When seen in the context of later developments in philosophy, the idealists often appear to eschew technical argument and definition. With the exception of Mitchell, the idealist approach to philosophy appears more literary in orientation, but also directed to a wider audience than much more recent work. A particular strength of the idealist approach to philosophy was the ability to bring multiple perspectives to bear on an issue, both critically and constructively. An example of this was the tendency to approach a key theme, such as the concept of personality, simultaneously from a moral, metaphysical, and psychological perspective. They typically sought to penetrate or to grasp an issue in its fundamentals, and subsequently to convey the insight they had gained to others. In the work of some of the idealists, it was clearly also their intention to motivate and inspire others in their own work.

As in Britain, idealism in Australia was a philosophy of engagement with moral and social issues. Many of its adherents made significant practical contributions to society and politics. Francis Anderson was notably influential in the reform of teaching in New South Wales and through a variety of other movements such as the League of Nations Union (O’Neil 1979). Mitchell became a prominent university administrator (Edgeloe 1993), as did others such as Morris Miller. In New Zealand, MacGregor was an important advocate of social Darwinist policies, having retained much of the influence of Herbert Spencer, who was widely reviled by most idealists (Tennant 1993; Tennant and Hanson 1979). William Anderson engaged with issues associated with educational reform and the development of 'self' and character (W. Anderson 1928, 1944).

\section{Henry Jones' Tour of Australia}

While the influence of Hegel, with its emphasis on the development of mind and on history, was less prominent in Australasian philosophy, it was the great Welsh philosophical orator and Hegelian Henry Jones (1852-1922) who provided one of the landmark events in Australasian philosophy.

In July and August 1908, Jones, Professor of Moral Philosophy at the University of Glasgow, undertook what must surely be the largest, and perhaps the only, blockbuster philosophical tour of Australia (Boucher 1990). Among those who attended his public lectures was Alfred Deakin, three-time Prime Minister of Australia, close friend of the American idealist philosopher Josiah Royce and himself recognised by a number of philosophers for his philosophical interests. Jones toured Sydney, Melbourne, Brisbane, Adelaide, Newcastle, and Wollongong. 
He was feted on his travels and drew audiences of up to 800 people to his lectures. His Sydney lectures were subsequently published as Idealism as a Practical Creed (Jones 1909) and became an important reference point for a variety of figures who sought to link the philosophical and the political worlds.

Jones had both personal and intellectual affinities with many of the philosophers and other key figures he met. In Sydney, for example, his friend Mungo MacCallum was Professor of English. In Melbourne, he dined with the Governor (a personal friend), Deakin, and Laurie, with whom he shared a deep admiration for Browning. In Adelaide, he met with Mitchell whose Structure and Growth of the Mind (1907) he had read for Macmillan.

Characterised as a 'preacher' of philosophy, Jones found a receptive audience for his message that the universe is a spiritual unity. He claimed that his Hegelian philosophy reflected the teaching of Jesus, and interpreted evolution as a theory that spiritualised nature. Jones was particularly important as a social and practical philosopher, building a case for State legislative intervention to provide the conditions for the development of character. In Australia he welcomed, and sought to inspire, social and political experiment. Both Deakin and H. V. Evatt welcomed his theoretical account of the breakdown of the opposition of liberalism and socialism that they each sought in practice (Boucher 1990; Hetherington 1924, pp. 103-109, 209-212).

It would be going too far to suggest that Jones' tour in itself had a lasting impact on the philosophical and political climate in Australia, but his sojourn is important for the light it sheds on the openness of Australian intellectual life at the time to idealist thinking.

\section{Early New Zealand Philosophy}

As in Australia, the majority of prominent early philosophers in New Zealand were from Scotland, although they often owed more to other traditions, rather than to modern idealism.

Commencing in 1871 at the University of Otago, Duncan MacGregor (1843-1906) was the first appointment to a Chair of Philosophy in New Zealand. $\mathrm{He}$ is perhaps best considered as a Spencerian and controversialist, rather than an idealist. Born in Aberfeldy, Perthshire, MacGregor studied at the University of Aberdeen and distinguished himself by winning a Fullerton, Moir, and Gray Scholarship in Classics and Philosophy at the University of Glasgow. He followed this with a medical degree at the University of Edinburgh. It was on the strength of his potential that he was made, at the age of 27 , the youngest professorial appointment at Otago and therefore the youngest in the country. Uniquely, MacGregor was the first at Dunedin hospital to perform an operation 'under Listerian principles of antiseptic surgery'. This was all the more remarkable as he was qualified as an academic of medicine and a health administrator, not as a surgeon! (Tennant 1993).

MacGregor is remembered less for his philosophical output and more for the force and nature of his personality as well as his radical views on social policy. 
An early defender of female emancipation, as well as an enthusiast of Spencerian principles of social Darwinism, MacGregor argued on grounds of social inclusion, and preparedness for 'the battle of life', that women should abandon Miltonian ideals of womanly submissiveness, eschew 'ivy drapery' and 'tawdry accomplishments', and be treated and regarded in exactly the same way as men (Tennant 1993). MacGregor was also noted for producing a series of articles on poverty, arguing that the colonies offered a chance to 'turn over a new leaf in the history of nations' (Coleman 1958; MacGregor 1876). However, MacGregor's rationale for this was Spencerian: 'the hopelessly lazy, the diseased, and the vicious' would normally be 'weeded out by natural selection', and it was the task of modern society to incarcerate the diseased, the dangerous, and the destitute (MacGregor 1876). MacGregor also appeared to be concerned about the 'contamination' of New Zealand society by lower races (Tennant 1993).

MacGregor created a storm of controversy when he advocated the study of evolutionary biology and sociology, coupled with a religious agnosticism (Numbers and Stenhouse 2000, p. 337). He also persisted in teaching evolutionary theory to students intended for the Presbyterian Ministry. This infuriated those who hoped he would be a safe appointment to the Chair. The Presbyterian Synod, and some influential church members, advocated that students withdraw from his classes and tried to prevent his further influence by unsuccessfully attempting to divide the professorial chair he occupied (Tennant 1993). MacGregor is probably the only professor of philosophy to forge a subsequent career as Inspector of Lunatic Asylums, a position he held from 1886 until 1898. In this capacity, he continued to advocate social Darwinism by means of a 'scientific' approach to welfare in his reports to parliament (Egarr 2006; MacGregor 1897; Murray 1944; Tennant and Hanson 1979).

William Salmond (1835-1917) was born and educated in Edinburgh where he studied theology, eventually becoming a minister in North Shields, England, for 17 years. He was appointed as the first professor of Theology at the Presbyterian Theological College in Dunedin in 1876. Following the publication of his The Christian Doctrine of Providence and Prayer and the Reign of Law (Salmond 1875), Salmond gained a reputation as an apologist for the 'reasonableness of Christianity'. This led to his succeeding MacGregor in the Otago Chair of Philosophy. The Presbyterian Synod of the time hoped for a religiously orthodox philosopher at the helm (Matheson 1993). He followed his appointment, however, with the publication of The Reign of Grace (Salmond 1888), a provocative document arguing for the compatibility of science and religion and decrying the 'intellectual terrorism' of Calvinism as inhumane. He was accused of hypocrisy and his views were denounced as heretical, although Salmond ultimately retained his appointment (Matheson 1993).

Salmond's replacement, Francis W. Dunlop (1874-1932), was appointed professor of philosophy at Otago in 1911. Like Boyce Gibson in Melbourne, Dunlop was associated with the work of Rudolf Eucken; Dunlop studied with Eucken and wrote his dissertation on Hegel: Hauptomente in Hegel's Begriff der Personlichkeit (1903). His philosophical output was scant, and his only known publication is Deep Love's Severity and Other Sermons (Dunlop 1908). 
Other foundation professorial appointments in New Zealand include C. F. Salmond, son of William, at the University of Canterbury (appointed in 1901) and Hugh Mackenzie (1861-1930) at Victoria University (appointed in 1899). Neither appointment led to major philosophical output (Gardner et al. 1973; History of Philosophy at the University of Canterbury; Salmond 1929, 1930).

Mackenzie's professorial chair was in English Language and Literature. However, in keeping with the spirit of the times, he was prepared to be "professor of things in general' including Mental Science (Ardley 1982). His only known writings, on aesthetics, the development of the English Language, and a variety of religious themes, remain unpublished (Mackenzie 1911, 1917a, b, 1921).

Mackenzie's work at Victoria was supplemented by the arrival of Thomas Hunter (1876-1953), an English rationalist philosopher, appointed in 1907 to the Chair of Mental Science and Economics (later Mental Science and Moral Philosophy). Hunter was strongly influenced by the psychological work of William Wundt, E. B. Titchener, and William Rivers and applied the new theories and experimental approaches developed in Europe to problems of perception and learning. He became Principal of the university and then its first Vice Chancellor and was knighted in 1939 (Beaglehole 1946, 1951, 2007). However, like MacGregor, Dunlop, both Salmonds, and Mackenzie, Hunter produced little in the way of philosophical publications; what he did produce bore evidence of his psychological interests (Hunter 1924, 1927, 1928, 1932, 1952). However, he did leave behind the first experimental psychology laboratory in New Zealand (Brown and Fuchs 1971).

The only other New Zealand philosopher besides Dunlop to hold discernibly idealist views, and who did publish philosophical work, was John Anderson's brother, William Anderson (1889-1955). Like his brother John, Anderson was educated in Glasgow under Henry Jones. Like John, William found a professorial post in the far-flung colonies. Anderson succeeded the indefatigable New Zealander J. P. Grossman (1865-1953) to the chair at the University of Auckland in 1921 (Ardley 1982). During his tenure, Anderson was influential in promoting quasireligious, Aristotelian, and democratic strands of idealist thought, especially as they applied to educational policy. He exhibited 'an antipathy to state control and centralised administration', a commitment to rationality, and an 'instinct of decency faithful to the common man' (Ardley 1982, pp. 18-20). William Anderson entered the fray of educational reform, arguing in The Flight from Reason in New Zealand Education that it was wrong that only the wealthy could afford "what has hitherto been the right of all, a grammar-school education' (Anderson 1944, p. 7; Collins 2003).

While not as prolific as his younger brother across the Tasman, he did leave a number of papers on topics as diverse as 'Psycho-biology and Democracy', 'Self', and 'Academic Freedom' (Anderson 1923b, 1926, 1928, 1930b, c, 1934, 1938a, b). His philosophy has been described as being written in the language of Bradley, Bosanquet, Caird, and Green, but being 'directed to the pregnant simplicities of reflective common sense and to the cultivation in his students of theoria and phronesis in a manner which would have won Aristotle's approval' (Ardley 1982, p. 18). 
According to Anderson, 'Philosophy is the theory of practice', 'coextensive with political theory', and 'the nearest analogue of philosophy is to be found in the deliberative and legislative functions of a democratic community' (Anderson 1923b, pp. 241, 246). The aim of philosophy, moreover, is mental contemplation, from which flows good deliberation and morally correct practice. Naturalist views of the world, according to Anderson, are misguided in abandoning the importance of reflective contemplation. They have got the 'world the wrong way up' (Ardley 1982, p. 19). This anti-naturalist attitude informs Anderson's views on the nature of mind and consciousness. In his paper on 'Self', for example, Anderson argues for an account of self as a 'supreme universal', distinct from its various particular realisations (Anderson 1928). In view of John Anderson's philosophical trajectory on matters concerning naturalism and the self, nothing could be more different. Intellectually at least, the Anderson brothers may well have stared uncomprehendingly at each other across the Tasman.

In contrast to the early New Zealand philosophers, their Australian counterparts were relatively prolific, and in the following sections we detail some of the concerns of each of the major Australian idealists.

\section{Henry Laurie (1837-1922): Australia's First Professor of Philosophy}

Henry Laurie was the first person to be appointed to a chair of philosophy in Australia, a position he held from 1886 to 1911. This appointment occurred following the secession of Philosophy from the Classics department at the University of Melbourne in 1881.

Laurie is now remembered largely for his founding role in academic philosophy, and particularly for having written an article advocating the creation of a chair in philosophy shortly before being appointed to a lectureship in philosophy in 1881 . Laurie was, however, highly regarded as a teacher and for his critical commentaries. More than a century later, his book Scottish Philosophy in its National Development remains a clear and insightful discussion of the leading Scottish thinkers from the early eighteenth century onwards (Laurie 1902). Laurie adopted a consistent critical position throughout the book, which drew on a Kantian theory of knowledge and a moral theory continuous with the idealist revival of the late nineteenth century. In Passmore's view, Laurie attempted 'to retain the distinction between God, the individual mind, and nature ... by grafting quasi-Kantian idealism onto a Scottish common-sense stem' (Passmore 1963, p. 140).

Born in Scotland in 1837, Laurie studied at the University of Edinburgh, where he came under the influence of A. Campbell Fraser. He never graduated, having suffered from poor health. Instead, he emigrated first to Canada and then to Australia in 1864, settling at Warrnambool, where he became town clerk and then a journalist. In 1877 he co-founded the Warrnambool Standard, which continues to this day (Smith 1986, pp. 7-8). Laurie, like Quaife, therefore enjoyed the distinction of having been a newspaper editor before becoming a professional 
philosopher. During and after his professional career, Laurie continued to participate in broader public life, publishing journalistic pieces, poetry and work on ethics, Browning, and Plato.

Browning's poetry was particularly important to Laurie, whose philosophy reflected many of its themes. For Laurie, Browning showed the ability of art to lead philosophical thought; Browning was interested in the world of thought and feeling, rather than that of action. For Laurie, Browning's poetry explored an aspiration towards an ideal, rather than an ideal attained. Browning showed a 'faith that a wise and good Intelligence is at the heart of things, that the world is the manifestation of a loving purpose, and that even sin and sorrow are subservient to the good'. Yet Browning's faith also held that the power for good 'demands the moral activity of man' (Laurie 1889, 1912, pp. 59-60).

\section{Laurie's Idealism}

Laurie was known for the fairness of his critical appraisals of the work of others; Grave noted that even Laurie's students had difficulty identifying a clear philosophical orientation in his work. Grave nevertheless characterised Laurie as 'a sort of idealist, an idealist of the sort disposed to regard itself as a sort of realist' (Grave 1984, p. 16). The comment might also be made of many others in the tradition, whose idealism implied contact of the mind with the reality in which it participated. Idealists such as Henry Jones, for example, denied the possibility of epistemology, because it was a theory of the mediation of mind and reality.

Miller, who had been a student of Laurie and wrote a lengthy appreciation of his work, stressed that he had been a critical thinker rather than a systematic one (Miller 1930, p. 5). Nevertheless, to be an idealist at this time was certainly to hold, more or less explicitly, a systematic conception of philosophy and of reality. Indeed, Miller drew attention to several elements in Laurie's philosophy that point to an inherently unified view, including his treatment of psychology as a propaedeutic to philosophy, as well as a focus on moral experience.

In his last published work, Plato in English Literature, Laurie identified Plato as 'a great Idealist', but distinguished three kinds of idealism. The first kind of idealism resolves all knowledge into 'sensations or other states of Mind'. This 'subjective idealism' was a 'heresy' that could not be attributed to Plato (though it fits a common caricature of idealist thought). The second kind of idealism emphasises the role of ideals in human life, both in terms of our ability to form them and to pursue them. This makes Plato and everyone else an idealist, and Laurie chose rather to restrict this definition to those who pursue 'worthy ideals'. The third type of idealism was, however, the most important. In the third sense, idealism is a 'theory of the universe' or of 'reality'. The highest ideals we pursue are taken to be a clue to reality, and the world is interpreted in their light. The good, the true, and the beautiful become concepts through which to interpret the Universe. Plato was to be understood as the 'great protagonist of Idealism' in this sense, but Laurie also cited the personal idealist A. S. Pringle-Pattison in this regard (Laurie 1921, pp. 2, 4-6). 
Laurie did not call himself an idealist in any of the three senses, although his affinities were most clearly with the second and third definitions. His clearest personal statements were either as an advocate of 'mental philosophy' in general or as a staunch critic of materialism. In his 'A Plea for Philosophy' from 1881 and 'The Study of Mental Philosophy' of 1885, Laurie argued for the key role of philosophy in civilisation and education while recognising the pragmatic and 'utilitarian spirit of the age' (Laurie 1881, p. 76). Nevertheless, he argued that philosophical questions could not be avoided. Philosophical positions were betrayed in the work of, for example, physical scientists and theologians. They were also explored by the poets: Wordsworth, Tennyson, and Browning could in fact be said to have been in advance of philosophical thought. Philosophy in the late nineteenth century, and particularly in the British universities, was renascent, largely through the renewed stimulus of continental European thought. The study of philosophy was therefore an essential aspect of student contact with the directions of modern thought and the intellectual traditions out of which it had arisen (Laurie 1881, 1885).

\section{Laurie's Theory of Mind}

Underpinning Laurie's view that philosophical questions could not be avoided was a Kantian view of knowledge, which is evident throughout all of his writings. Against the view that knowledge arises out of experience alone, he maintained that mind 'contributes certain elements of cognition'. In particular, it provides the key concepts of universality and necessity which support scientific and practical experience alike. Knowledge is 'experience plus the thinking mind'. Laurie held that this was in itself sufficient to dispose of materialism, since materialism as it stood sought to explain knowledge by reference to the material world and the effects of sensation (Laurie 1881).

The theory of knowledge was, however, less important to Laurie's philosophy than the metaphysical aspects of his theory of mind and his moral philosophy. In a substantial piece on 'Materialism', from 1907, Laurie set out the reasons why he rejected materialism. Mental facts and physical facts are distinct and mental facts are never resolvable into physical facts. Therefore they are not resolvable into biological facts either (Laurie 1908).

Laurie was prepared to follow the notion that there is a science of the brain and that this would show that mental facts are 'changes in the nervous system'. But material facts and mental facts differ significantly. A material object occupies space, but mental facts (such as mental objects or mental acts) do not. The two may be correlated, but are always distinct. Nor are mental facts a form of motion of the brain, and mental actions are not properties of material things; the brain is not the mind, and the mind is not the brain. Whereas we can seek to be acquainted with physical facts by attending to them, we become acquainted with the mind by introspection. Similarly, while matter involves energy, there is no equivalence between volition and muscular movement. Where the materialist theory explains 
how physical causes produce physical effects, it cannot explain how consciousness can be a by-product of such causal chains. Nor can it, therefore, explain how mental life is full of activity and life. Following G. F. Stout, Laurie argued that, on the materialist theory, 'mind has no efficiency within itself. We do not direct our thoughts or imaginations... man as a conscious being never does anything at all' (Laurie 1908, pp. 250, 256).

\section{Laurie's Moral Theory}

The moral sphere was, for Laurie as for most other idealists, both the distinguishing point between the world of the mind and the world of physical science, and supremely active and self-governing. In 'Materialism', Laurie drew attention to the world of our mental experience as representing a 'unity of consciousness' in a 'continuous series'; it is only in such terms that man can be understood. The unity of consciousness, however, brings a new character into the world, of which a theory of the universe or of reality must take adequate account (Laurie 1908, pp. 259-260). In his criticism of Reid, Laurie argued that moral actions are influenced by moral motives, but that they go beyond this and express character. Personality is free, not in the sense of being independent of motives, or apart from them, but in the sense of being able to form and act on moral ideals- 'there is nothing parallel to this in the sphere of physical causation' (Laurie 1902, p. 158). Moral causes produce moral effects. Moral intuitions, he argued, involve the pursuit of ideals, which have changed over generations. These intuitions cannot be explained by hereditary transmission of acquired characteristics, but only by the handing down of moral precepts in writing, orally, and in examples, including through punishment (Laurie 1903).

Science and philosophy alike presuppose that the world is intelligible. For natural science, this intelligibility comes from concepts such as causation. For the moral sphere, it comes from the experience of ends, purpose, and choice. In 'Materialism', Laurie ventured the view that the mechanical world might also be subject to the concept of ends. The material world could be understood only in relation to thought. Intelligence combines qualities into precepts; mind is constructive, and the distinction between mind and matter arises only through the activity of thought. Far from mind being an effect of matter, matter exists only as related to mind. A unified account of the world would be achieved by showing that the mechanical world and the moral world are in fact united under concepts that apply to mind, particularly the concept of purpose. The theory of evolution would be preserved because the universe would be read in the light of the highest features of evolution. Indeed, the evolution of the universe would no longer be seen as 'a succession of aimless changes; it is instinct with purpose, shot through and through with thought' (Laurie 1908, p. 262).

It seems, then, as if Laurie had, at least at some point in his career, succumbed to the 'heresy' of abolishing matter by resolving it into mind. But this would be to misunderstand his point. Laurie sought to preserve a unitary explanation of the 
world. He had rejected materialism as a sole explanatory causal factor. Laurie rejected parallelism because it violated the concept of a single universe and he could not accept that mind and matter were completely isolated from each other (Laurie 1908, p. 258). He maintained their distinction but offered the interpretative concepts of ends and purpose, which he held to be fundamental to the moral world, as the basis for the interpretation of the universe as a whole. The unity of the universe is interpretative, rather than reductive.

Perhaps the most remarkable of Laurie's published papers is his lecture 'Some Thoughts on Immortality' (1901), which brings together many of his key themes, and strikes an unusual balance between the critical and constructive tendencies in his thought. Laurie followed Kant in rejecting any argument for immortality based on the nature of the soul and in turning attention to the moral argument. This is an argument that we pursue as our highest goals ends which can be attained; there can be progress towards an ideal. Laurie noted, though, that Kant anchored his argument in a relatively weak case for the existence of God. Laurie's own response was to focus on elaborating the moral argument, preserving immortality as a plausible hypothesis (Laurie 1901).

Science presupposes that the world is an intelligible system, and Laurie extended this assumption to religion and morality. When the universe is seen as rational from the perspective of morality, it is difficult to see it as being so irrational as to permit the pursuit of ideals that can never be fulfilled, and then for the pursuit to end abruptly in death. Materialism would hold otherwise, but materialism fails because mind cannot be reduced to a by-product of physiological change. Matter can be 'conceived only as related to sentience and thought'. The idea that the soul perishes with the death of the body has as much plausibility as the idea that it survives. The hope of immortality cannot be abolished by any argument about the relationship of mind and body. Neither can any hypothesis about immortality be proved as if it was a scientific hypothesis. There is no ground for dogmatic assertions about immortality, either for or against. But the hope may be found, as with Tennyson and Browning, conjoined with ethical feeling. It is a belief not a desire, one that results from interpreting the universe from a moral perspective: 'To one in the plenitude of life, life approves itself and gives promise of its continuance' (Laurie 1901, pp. 22, 25).

\section{Francis Anderson (1858-1941): The Christian Idealist}

Francis Anderson's role in Sydney philosophy was akin to that of Laurie in Melbourne. Anderson was the first Challis Professor of Logic and Mental Philosophy, a position he held from 1890 until 1921, having first been made Lecturer in Logic and Mental Philosophy in 1888. Like Laurie, Anderson was a Scot who emigrated first to Victoria in 1886; unlike Laurie, Anderson had a strong background as a professional philosopher (Lovell 1941; O’Neil 1979).

Anderson was a graduate of the University of Glasgow, where he had a very successful career. As the result of winning a fellowship, for 2 years Anderson 
became an assistant to Edward Caird. He also pursued theological studies and taught English literature.

Since his death, Anderson's reputation has rested on his contributions to the broader field of education reform. He was involved in a considerable expansion of the scope of university teaching. The subjects he promoted ranged from economics, politics, sociology, and psychology to teaching. Anderson also played a key role in redefining the expectations of a university education.

Anderson was particularly influential outside the university, in areas ranging from adult education to the school system in general. His early experience as a fourteen-year-old 'pupil-teacher' in Scotland fortified his criticisms of the school system, and his commentaries provoked a commission that led to the abolition of the 'pupil-teacher' system in New South Wales and its replacement by a Teachers' College. Among his other pursuits, he edited the Australasian Journal of Psychology and Philosophy, was Chairman of the Council of Social Service, and State President of the League of Nations Union. His first wife, Maybanke, was a prominent suffragist and social reformer who he met through the Kindergarten Union (Roberts 1997).

In an age when philosophers often taught across wide areas, Anderson had perhaps the largest brief of any of the early teachers, although he was eventually able to relinquish the teaching of psychology to an assistant, H. T. Lovell. As with many of the early figures in Australian universities, Anderson was a revered teacher, renowned for his sincerity, passion, charm, earnestness, and a relative familiarity with his students (Lovell 1941, pp. 99, 101).

\section{Anderson's Christian Idealism}

Anderson has been variously described as an 'idealist and liberal' or a 'Christian idealist'. Grave has characterised his key message as one of 'self-realisation'. Lovell concluded that 'Anderson's system was a generous eclecticism governed by a preference for moral philosophy and a keen interest in sociology... His position was at once idealist and liberal—an idealism which served to draw its main inspiration from Kant's Categorical Imperative, a liberalism which knew how to examine dispassionately the work of the Marxian school' (Grave 1984, p. 20; Lovell 1941, p. 101).

The moral concern predominates in Anderson's published work, but it was underpinned by a conception of the real as rational (Anderson 1923a, 1930a, 1931a, b, c, d). In a paper extolling the philosophy of T. H. Green, Anderson noted Green's constant practical and theoretical engagement with 'ethics and politics'. This should be seen as a corrective to the narrowness of English philosophy from Bacon, through Locke, to Mill and Spencer. But Green's moral philosophy itself emerged out of a broader concern to achieve a unity of knowledge. Green had placed development at the centre of philosophy and seen 'that all nature is a process of unfolding' that is animated by a 'spiritual principle which can only be described as thought or reason'. Indeed, there are 'ends immanent in nature', and 
it is with these that the 'scientific explanation of life' begins. And while it begins there, it cannot end there for, on this account of the world, religion crowns knowledge, and ethics flows from the spiritual character of the world (Anderson 1902, pp. 177, 186-188).

\section{Anderson's Views of Personality and Morality}

In his 1922 monograph, Liberty, Equality and Fraternity, Anderson argued that there had been four key revolutions in history, each of which was based on an ideal of 'liberty, equality, and fraternity', although not on the same form of each concept. There was first a spiritual Buddhist revolution, then a Christian religious revolution, a political revolution exemplified by that of France, and, finally, an economic revolution, still underway. Anderson assessed each revolution in terms of its moral and social dimensions. Buddhism was moral, but inwards in its orientation, and lacked an effective 'social gospel'. Christianity centred on personal life, but had been interpreted through a focus on individual conscience, rather than through its social aspect.

For Anderson, the principle of personality provided the only true foundation for civilisation as a series of reciprocal moral relationships. It also provided the basis for criticism. The French revolution, for example, was political and economic, but it had a purely negative focus on removing restrictions on action, rather than on the use of freedom; liberty, equality, and fraternity were formal and negative conceptions. The Russian revolution similarly failed to address the moral dimension of social and political problems, and Anderson argued that State collectivism could not be a means to achieve the 'full and free development of the activities of man as a moral and spiritual being'. In later years, Anderson was a fierce critic of totalitarianism in all its forms (F. Anderson 1922, p. 21).

To take a positive moral view of freedom is to seek to combine love and justice. Kant's moral law is a pointer to this, because it sees man as an end and not simply as a means. But the true combination of love and justice is only achieved in the idea of God. This draws reform back to the principle of personality, which Anderson saw as the foundation of Christianity. The story of history is the story of the unfolding or discovery of personality, but man breaks the limits of history in pursuit of his moral goal. The moral dimension is essential to make social and political reform into true reform, to make not merely a human life, but 'the good life' possible for all (F. Anderson 1922, pp. 17, 20-24).

\section{A New Civilisation}

The moral concern similarly underpinned Anderson's work with the League of Nations Union and his commentary on the developing crisis in international relations in the 1930s. He argued that conflict was inevitable in human affairs, but that war should not be equated with conflict. War arises from 'the same 
spirit of violence and domination, which is the fundamental evil in human nature'. It would never be enough to pursue military disarmament, without at the same time pursuing economic and moral disarmament. It was the last of these which was the most important. He saw the principles of the League as those of a true internationalism, of 'mutual tolerance, respect for law, and sustained rational control'. In turn, this was part of a broader movement to a new civilisation, whose economic, political, and social systems must reflect new ends and values, and which was promoted by increasing physical connection and economic integration (Anderson 1935, pp. 9, 42).

Anderson criticised leaders in whatever field who were seeking to hinder the growth of the new international civilisation through policies such as economic nationalism. He particularly condemned Capitalism, Communism, and Fascism alike for their narrow conceptions of man and dictatorships of all types for their attacks on freedom. Indeed, he regarded those who rejected the gospel of peace in favour of force exercised without responsibility as embodying the Anti-Christ. The question to ask in relation to support or opposition to the League of Nations was 'Who is on God's side?' (Anderson 1935, pp. 11, 25, 34).

\section{Sir William Mitchell (1861-1962): The Gifford Lecturer}

Scottish-born Sir William Mitchell, the Hughes Professor of Philosophy and Vice Chancellor at the University of Adelaide, was the first major philosopher to live and work in South Australia. From the commencement of the University of Adelaide in 1874 and until the appointment of Mitchell, the Hughes Chair linked Mental and Moral Philosophy with English. The holder was not expected to be a specialist in Philosophy (Miller 1929, p. 248n). Mitchell's first predecessor, the Rev. John Davidson (1834-1881), who studied at St. Andrews, was neither a philosopher nor a graduate and was not 'of any great culture' (Walker 1972). He was replaced by Irishman Edward Vaughan Boulger, who initially showed great promise and who was appointed to the chair in 1883. However, in 1894, Boulger 'resorted to stimulants' and resigned after failing to perform his duties ('Boulger, Edward Vaughan, 1846-?' 1969). Boulger was followed by Mitchell, who was the first real philosopher in Adelaide and certainly the first philosopher working in Australasia to gain significant recognition overseas. ${ }^{1}$

Mitchell was born in Inveravon in Banffshire, Scotland, in 1861. He was the son of a hill farmer and one of six children. Mitchell studied at the University of Edinburgh under Campbell Fraser, gaining his MA in Philosophy and then a D.Sc. by thesis in the Department of Mental Science in 1891. He reluctantly had a paper published in the journal Mind while still an undergraduate and, following this, was appointed as an assistant to Henry Calderwood. He was a lecturer in moral

\footnotetext{
${ }^{1}$ This section is partly based on the following publications and is reproduced with permission: Davies (1999, 2003, 2004).
} 
philosophy at Edinburgh (1887-1890), an examiner in Philosophy and English (1891-1894), and a lecturer in Ethics and Education at University College, London, and at the University of Cambridge during the same period. He also spent time as a lecturer and examiner in English for the Royal University of Breslau in Germany (Edgeloe 1986).

In 1895, Mitchell accepted the Hughes Chair in English Language and Literature and Mental and Moral Philosophy at the University of Adelaide, having declined the Chair of Philosophy and Economics at the University of New Brunswick, Canada, on health grounds (under threat of tuberculosis). He held the Chair in Adelaide from 1895 to 1922 (Boucher 2004; Davies 2003; Edgeloe 1986). Mitchell retired in 1948 at the age of 87, having served as Vice Chancellor (1916-1942) and later Chancellor (1942-1948), and serving on University Council for 52 years (Edgeloe 1986). He was the first (and to date only) philosopher working in Australia to give the Gifford Lectures, at the University of Aberdeen in 1924 and 1926. In 1927 he was knighted for his services to South Australia (Miller 1929). An impressive building at the University of Adelaide and a State electorate in South Australia are named after him.

\section{Mitchell's Administrative Contributions and View of Education}

Mitchell is remembered as an important administrative figure at Adelaide University. He was highly successful in obtaining government grants for the university. $\mathrm{He}$ also founded the Chair of Biochemistry (in which he installed his son, Mark); spent large sums on library acquisitions; and made many administrative contributions, mainly in the field of Education. These included dramatically restructuring the arts curriculum to provide 'a general education in opposition to the widely-accepted view that education was simply a means for "getting on"" (Edgeloe 1986, p. 535). Like Francis Anderson in Sydney, Mitchell's early education committed him to the importance of education as 'the formation of an intellectual, an aesthetic, and a moral character, together with various kinds of skill' (Boucher 2004; Edgeloe 1986). Central to this was the education of teachers themselves. To this end, Mitchell embarked on an ambitious plan known as the Mitchell-Bragg plan. This included forgoing university fees for 2 years for trainee teachers in undergraduate studies, who were housed within the university. This eventually resulted in Education becoming a separate bachelor's-level degree. In parallel, Mitchell also established an independent teacher training college with its own governing body (Edgeloe 1986).

In the educational climate of the time, Mitchell's views on education were quite radical. He claimed that the fragmentation of knowledge by reason into a variety of 'isms' was part of the problem in education. It had resulted in schools and universities trying to cover too much ground at the expense of considerations of practice and interest. The aim should be to remove the emphasis on dispassionate reason and return to considerations of value: 'Reason is no substitute for [living value] any more than physiology is a substitute for breathing and digesting' (Mitchell 1937, p. 7). 
For Mitchell, this pointed to the need for an education system which provides opportunities for 'tacit knowledge' to be explicitly modelled by teachers. On Mitchell's view, the teacher models more than explicit rules: he or she also models implicit understanding. This provides an argument for the importance of practical education. Practical education fosters the intrinsic merit of interest and application and does not devalue practice in place of explicit learning via examinations (Mitchell 1895). True understanding, according to Mitchell, requires interest and attention to be generated, time to reflect and ponder, opportunity for explicit modelling of desired routines, and a forum for practicing what one thinks implicitly: '[T]he measure of value of . . . education is not the quantity of knowledge which it conveys, but that character and permanence of the interest it creates' (Mitchell 1895, p. 15). Elsewhere, Mitchell outlined his 'model' university:

There would be no examinations, no essays, nor even any prescribed readings; and there would be no fee. But I should make attendance compulsory for the greater part of one year in about a student's third year, and voluntary thereafter. The route would, I believe, soon reach a stage where lectures would give place to discussion; and, from the start, the professor in charge would be more the director of a clinic than a lecturer. We might call him a professor without portfolio, because he is for all students. He would be familiar with philosophy, but he would have a province of his own, and no chair in the university would have its province better defined. (Mitchell, 1937, p. 3).

Mitchell was considered something of a polymath, being engaged to teach economics and education as well as philosophy, psychology, and literature. It might be disputed how much teaching he actually did in economics and literature-though a recent publication claims that he taught economics four evenings a week in addition to his other duties as Professor of Philosophy and Vice Chancellor (Economics at Adelaide 2003). There is no doubt that he was a man of considerable energy. It was perhaps for this reason that he famously described his professorial chair not as a chair but a sofa. Mitchell was also said to be an easygoing character, 'with absolutely no pretentiousness or pomposity about him' (Edgeloe 1986).

Mitchell wrote two books: his main work, Structure and Growth of the Mind (1907), and The Place of Minds in the World (1933). He also published a number of shorter papers on a variety of topics including 'Reform in Education', 'What is Poetry?', 'Lectures on Materialism', 'Christianity and the Industrial System', 'Nature and Feeling', 'The Quality of Life', and 'Universities and Life' (Mitchell $1895,1898,1903,1912,1929,1934,1937)$. Mitchell was also a regular contributor to the early editions of Mind and frequently wrote shorter pieces for newspapers on topical issues, such as the First World War. He argued for a patriotism that concentrated on 'the country's task, welfare, honour, and shame', as opposed to simplistic and jingoistic 'us versus them' nationalistic accounts (Edgeloe 1986; Mitchell 1918).

Because of his considerable abilities as an academic, administrator, and social commentator, Duncan and Leonard describe Mitchell as 'the nearest approach to 
a philosopher-king the academic world has ever seen' (Duncan and Leonard 1973, p. 78; Trahair 1984). Australian philosophy, it may be said, has seen no one like him, before or since (Thom 2007).

\section{Mitchell's Philosophical Writing}

Mitchell always considered himself to be, first and foremost, a philosopher (Smart 1962). Curiously, however, he is not remembered at all as such, and-like W. R. Boyce Gibson and Francis Anderson-in academic terms he is today a largely forgotten figure (Davies 2003). Until very recently, the last critical discussion to appear in print on Mitchell's work was probably in Blanshard's Nature of Thought in 1939 (Blanshard 1939); the last review of his books appeared in 1934 (Acton 1934; Harvey 1934). Little mention has been made of Mitchell in contemporary philosophical writing. In Honderich's Dictionary of Philosophy, Mitchell's Structure and Growth of the Mind is described as the last remaining example of Australian idealism which 'still survives' (Honderich 1995).

The contemporary neglect of Mitchell's work is in sharp contrast to the widespread praise he received for Structure and Growth of the Mind. Blanshard cited it extensively and confessed he owed Mitchell a 'large obligation' (Blanshard 1939, p. 97); Henry Jones, a normally severe critic, also outlined its merits in a reader's report by noting: 'it is extraordinarily strong and manifests throughout the most thorough philosophical grasp' (Boucher 2004). Norman Kemp-Smith praised it as 'undoubtedly one of the most important philosophical publications of recent years' (Kemp-Smith 1908, p. 332), and R. F. A. Hoernlé said: 'In a book where almost everything is good, it is hard to single out special points to praise' (Hoernlé 1909). J. R. Harvey rated Mitchell's second book, The Place of Minds in the World, as 'a book of first importance' (Harvey 1934, p. 106).

His contemporaries were, however, also highly critical of Mitchell's style. Even allowing for the conventions of the time - and taking into account the difficulty of the philosophical concepts he was engaged with-his work is badly written: often divorced of clear central themes, lacking in detailed exegesis, and ponderous in delivery. (A professor of classics at Adelaide at the time 'used to say that he could never understand Mitchell's books until he had translated them into Latin'.) (Duncan and Leonard, 1973, p. 19; Grave 1984, p. 22) One reviewer of Structure and Growth of the Mind pointed out that, while reading it, one always has to 'retrace one's steps and grope for the context'. The same reviewer complained that, because of 'no contour or difference in emphasis', reading the book was like 'swimming under water with never a chance to come up and look about' (Perry 1908, p. 45). Everybody, except Mitchell himself, found his work virtually impenetrable, particularly The Place of Minds in the World. A modern-day reader of Mitchell outlines the problem as follows: 'No professional philosopher these days reading for a publishing house (except perhaps for those wallowing in the slough of postmodernism) would let Mitchell get away with it' (Mortensen 2005, p. 300). More kindly, Passmore called Mitchell's books 'very obviously, the products of a solitary thinker' (1962, p. 145). 


\section{Mitchell's Philosophical Influences}

A wide range of influences, idealist and empiricist, can be traced in Mitchell's philosophy (Davies 2003). From the common-sense philosophers such as Thomas Reid, Mitchell took the arguments advanced against solipsism and anti-realism. From T. H. Green, Mitchell derived the idea that an uninterpreted sense datum was simply folly. From F. H. Bradley, Mitchell took the idea that experience-at least initiallyis a seamless unity of knower and known. From James Ward, Mitchell drew the important idea that organisms grow and an adequate explanation of mental activity must capture this. From William James, Mitchell gained an 'empiricist streak' (Thom 2007). Despite being often recognised as one of the 'triumvirate of early Australian idealists' (Franklin 2003; Grave 1976; Kennedy 1995, p. 75), alongside Laurie and Anderson, Mitchell always insisted in conversations with J. J. C. Smart, a successor in the Hughes Chair in Philosophy, that he was a staunch realist (Smart 1962).

Mitchell developed complex views on the relationship of mind and matter, which suggest that he was neither an anti-realist nor an anti-materialist, even though he did reject any simple-minded reductionism of mind and matter. Instead, he argued that:

\footnotetext{
...When you try to picture the structure and the action of the mind, remember you are trying to picture the structure and action of the nervous system. In this way you will avoid the usual confusion of trying to picture a hybrid process consisting partly of visible movements and partly of invisible feelings. (Mitchell 1907, p. 7)...

...A mind and its experience are realities that are presentable to sense as the brain and its actions. In that respect the mind and experience are not parallel with nature, but part of it. And, on the other hand, the facts of nature, including the brain, whenever they are phenomena, are not parallel with mental phenomena, but part of them. (Mitchell 1907, p. 23)...

....As a thing in nature, as visible, tangible, occupying room, etc., the mind and its experiences are the brain and its processes. (Mitchell 1903, p. 10).
}

Passmore might have been only partly right when he described Mitchell's work as articulating 'an introduction to an idealist philosophy for which the mind is the central ontological conception' (1963, p. 146). Certainly, for Mitchell, the role of the mind and experience is a pre-eminent consideration. Perhaps the best way to understand Mitchell's thought is to see him as articulating a methodological idealism: the mind and its experiences are the way by which one can understand the brain and its processes.

Like other early Australian idealists, Mitchell gave appropriate acknowledgement to the development of materialist natural sciences. He more readily accepted, however, the findings of natural science that related to the nature of mind, even though he eschewed any simplistic reduction of 'mind and matter'. It was this that made his account of consciousness very complex indeed. Mitchell certainly did not work in the spirit of the Christian Idealists in Australia at the time, such as Francis Anderson, nor the 'personal idealists' such as W. R. Boyce Gibson. Neither did he attempt to run the gauntlet of their criticisms. Instead, he remained 'isolated in Adelaide and uninterested in philosophical controversy' (Passmore 1963, p. 148). Mitchell appeared to borrow what he liked from idealism and set about constructing his own very idiosyncratic system. 


\section{Mitchell's Philosophy of Mind}

Mitchell's philosophical contributions had as their focus the nature of mind and experience. His particular interest was in the growth of the mind, and, to a lesser extent, its ontology. The key elements of his thought are easy enough to state in general terms: experience is the crucial element of our mental lives, or, to put it another way, 'mental activity is central in experience' (Miller 1929, p. 249). However, Mitchell was not merely interested in such conscious experiences. He recognised that not all experience is conscious, but is nonetheless important to the growth of the mind. Experience, for Mitchell, covered everything from sensory content, or qualia, to high-level intentional content at various levels.

For Mitchell, there was no principled epistemic divide to be drawn between the levels of experience. One learns about the mind primarily by studying experience directly as we live it (the 'direct' approach) and secondarily by studying the mind indirectly by means of the emerging sciences of the mind, for example, neuroscience (the 'indirect' approach). Knowledge acquired by means of the direct approach aids in directing attention to relevant features of the indirect approach. Mitchell noted that it is only because we have phenomenal experience that we can make sense, and give meaning to, brain processes - which he viewed as the neural correlates of experience (Mitchell 1903, pp. 10-11). This reverse-engineering approach is surprisingly contemporary. It is identical to recent approaches that use phenomenal experience to provide resources for the empirical findings from the cognitive and neurological sciences. These days this is sometimes known as the 'natural method' (Davies 2003, p. 180; Flanagan 1992; van Gulick 1993).

The action of mind is always action on an occasion (Miller 1929, p. 249). The occasion, according to Mitchell, is the moment and conditions under which an experience happens and the content that such conditions bring about. The occasion is a stimulus property (either mental, physical, or environmental). Experience is what the mind, the 'reacting structure', does in reaction to its environment. The organism aims to resolve occasions in order to achieve pragmatic and experiential ends. Thus, we focus our eyes to achieve a better view. However, this also occurs at higher levels. So, for example, our concepts are deployed in making sense of more complex experiences. Organisms start off by resolving low-level instinctual experiences and then move to higher, more satisfactory levels of experience, though there might be evolutionary and experiential constraints on particular creatures. As the idea of resolving experiences is a key to Mitchell's account, this leads to an account which demands levels of experiential content.

The sensory level is roughly equivalent to instinct. Some organisms remain at this level and advance no higher. As Mitchell defined it, the course of instinctive action is 'the power of pursuing an infinite variety of course [sic], directed throughout by present sensation' (1907, p. 194). The next level is perceptual intelligence, which is equivalent to content which already comes with the power to anticipate further experiences (e.g., we simply 'see' a display of objects and know how to react; we don't have to infer our course of action). This has a number of levels 
(feeling, practical and cognitive interests). Some organisms - some humans-even remain at these levels. The last level is cognitive intelligence which is influenced by rules, language, and principles, and it helps differentiate the expert from the non-expert.

On the metaphysics of mind, Mitchell argued that the capacity to experience allows an inference to the notion of mind (Allen 1984, p. 7). This is rather different from some current approaches which regard the capacity to experience as a reason to deny the existence of mind (Churchland 1979, 1986, 1988; Dennett 1988, 1991) By complete contrast, Mitchell thought that the very structure of experience is evidence that mind exists (otherwise there would be no evident structure).

Contemporary philosophers refer to the 'easy' and the 'hard' problem of consciousness. The 'easy' problem consists in how brains might do things such as represent perceptions in thought in a neural or computational form; the 'hard' problem consists in explaining how things seem to us in experience (the 'what it is like' of consciousness) (Chalmers 1996). Mitchell developed his 'indirect' and 'direct' approaches to the mind over a century ago. The 'indirect' method offers a potentially complete understanding of 'the immediate physical correlates' of experience (Mitchell 1907, p. 450). The direct method offers an understanding of what experience is like 'from the inside'. Both approaches, according to Mitchell, are essential. This is surprisingly anticipatory of later discussions in the philosophy of mind in Australia and elsewhere (Davies 2003).

\section{Mitchell and Current Philosophy}

Of all of the Australasian idealists, it is Mitchell whose work resonates most closely with current concerns. It is particularly relevant to current thinking among cognitive scientists and philosophers of mind.

At the turn of the twentieth century, Mitchell was attempting something very new and original. He wrote on issues that are only today being discussed by philosophers and psychologists as 'cognitive science'. Mitchell was interested in science, and especially the psychology, physiology, and neurology of his day. He read and digested Baldwin's Mental Development of the Child and the Race (1906), Loeb's Comparative Physiology of the Brain (1900), and Campbell's Histological Studies on the Localisation of Cerebral Function (1905), among other texts, as well as a large number of scientific and medical journal articles (Davies 2003, p. 32n). In his series of Gifford Lectures he aimed to 'discover what conclusions about the place and power of minds emerge when due emphasis is placed upon philosophical and scientific inquiries' (Acton 1934, p. 243), an approach which can be said to have 'a very contemporary ring about it' (Thom 2007).

Mitchell's Structure and Growth of the Mind stands as a major (if now unread) treatise on philosophical psychology (Davies 2003; Mortensen 2005). He seemed to have anticipated the claims of the 'new mysterians' or 'new dualists' and their emphasis on qualia, or subjective experience (Davies 1999). He also seemed to have anticipated themes associated with perceptual plasticity and developmental 
accounts of the modularity of mind. Liberally interpreted, he might even be seen as prefiguring connectionist accounts of consciousness with his remarks about 'the localisation of sensation and intelligence' being 'spread over the entire cortex. The arrival platforms, or projection areas of mere sensation, extend each to an indefinite margin, which includes, without a definite dividing line, the parts that are concerned with organising the sensory elements into definite wholes and parts' (Mitchell 1907, p. 483). This was a remarkable a priori conjecture for 1907 and it is not, in essence, dissimilar from modern accounts: 'a percept is a pattern of activation over a set of processing units which takes place via the propagation of activation among units via weighted connections' (McClelland 1999, p. 137). ${ }^{2}$

Mitchell's first book ranged over issues in mind and content, philosophical psychology, and neuroscience. His second book covered issues overlapping mind and the philosophy of physics. This included the then relatively new area of quantum mechanics. The only copy of the third manuscript of The Power of Mind - intended as part of a trilogy - is said to have been lost during the London bombing raids in the 1940s. There are, however, surviving manuscripts of this last book and summaries of the Gifford Lectures (Mitchell 1926). Regrettably, none of these has ever reached print.

\section{William Ralph Boyce Gibson (1869-1935): A Philosophy of Immediate Experience}

Like Mitchell, W. R. Boyce Gibson is now relatively little known in Australian philosophical circles. A chair and a Departmental library at Melbourne University commemorate the contribution that he and his successor, his son Alexander, made as Professors of philosophy from 1912 to 1965. W. R. Boyce Gibson's translation of Husserl's Ideas remains well known, but his prolific writings across a wide range of philosophical concerns are now rarely read. ${ }^{3}$

Gibson, like John Anderson in Sydney, was a student of Henry Jones at Glasgow. Both Anderson and Gibson reacted against Jones' absolutist form of idealism. Anderson became a vigorous and distinctive realist. Gibson took an altogether different path, turning first to an alternative movement known as personal idealism, and subsequently attempting to show how the conflict between absolute and personal idealism could be overcome by reinterpreting absolute idealism on personal idealist lines.

Gibson was born in Paris in 1869. His father William was a Methodist minister, while his mother, Helen, was the daughter of a prominent Wesleyan. The religious element ran strongly in Gibson's subsequent philosophy and family life, with his brother and one of his sons becoming ministers, and he and Alexander making religion a key theme of their philosophical work. Philosophy ran strong, as another

\footnotetext{
${ }^{2}$ Space does not permit an outline of these themes. For a detailed account, see Davies (1999, 2003).

${ }^{3}$ This section draws on Helgeby (2006), with permission.
} 
son, Quentin, also became a philosopher. His son Ralph became a leading figure in the Communist Party, which his widow, Lucy, also joined after his death (Boucher 2005; Grave 1981; Merrylees 1935).

Gibson's early training and career were in mathematics. This interest in mathematics survived into his later work in two forms-through a concern with contemporary developments in physical science and in his work on logic. His turn to philosophy involved studies in both Paris and Glasgow. Rudolf Eucken exerted a particularly strong hold. Gibson undertook a number of translations of Eucken's work with his wife Lucy, as well as a full-scale commentary on Rudolf Eucken's Philosophy of Life (Boyce Gibson 1907).

The attraction of Eucken was his attempt to develop a life-philosophy that was also a philosophy of reality. Eucken articulated a spiritual philosophy and sought to 'detect the working of this cosmic life within us'. Spiritual life should be seen as a development of the universe, appropriated through faith, and existing as 'ceaseless conflict'. For Eucken, life in the twentieth century must seek to reconcile rationalism with the historical approach and to renew Christianity in a new 'passionate' and 'constructive' phase of religion, grounded in life (Boyce Gibson 1907, p. 3; Eucken 1909).

Gibson became Professor of Mental and Moral Philosophy at the University of Melbourne in 1911, arriving in Australia in 1912; he served from then until 1934. He came to Australia with his reputation established and having published books on ethics, Eucken, religion, and logic. While he envisaged a second volume on logic, he did not write it and produced no further books. Instead, his philosophical output in Australia was largely in the form of journal articles, themselves often lengthy multi-part treatments of particular philosophical issues or philosophers. It might be speculated that the teaching obligations of philosophers in the early twentieth century were not conducive to writing books. Nevertheless, university life clearly allowed considerable opportunity for the study of the work of other thinkers, for Gibson contributed papers on a variety of contemporary continental thinkers such as Nicolai Hartmann (Boyce Gibson 1933a, 1934, 1935) and Melchior Palagyi (Boyce Gibson 1928a, b), and also studied with Husserl.

\section{Gibson's Personal Idealism}

Throughout his philosophical career, Gibson consistently identified himself as a personal idealist or 'personalist'. Personalism has a long history, continuing from the late eighteenth century in Continental philosophical thought and surviving in a number of forms, both in Europe and in America (Bengtsonn 2006). English personal idealism was influential from the turn of the twentieth century until the 1920s, but was preceded by that of the Scot A. S. Pringle-Pattison, whose work was prominent from the 1880 s onwards. Personal idealism was seen as a significant alternative to both the naturalism of nineteenth-century thought influenced by science and the absolutism of the British Hegelians. 
Personal idealism shared elements with naturalism as well as with absolute idealism. With naturalism, it shared a focus on experience, but denied that naturalism gave an adequate account of that experience. In particular, naturalism was said to provide an inadequate account of personality and moral action. With absolute idealism, personalism shared the view that reality is ultimately spiritual, and similarly denied that absolute idealism gave an adequate account of human experience. In particular, absolute idealism was said to provide an inadequate account of human volition. In the collection edited by Henry Sturt, Personal Idealism, personal idealism was said to issue in an 'empirical idealism' that linked 'a spiritual philosophy and empiricism' through 'personal life' and 'the study of common experience' (Sturt 1902, pp. v-viii).

Gibson focused on immediate experience but, unlike some other personal idealists, he ventured a view of the absolute. Indeed, he sought to bridge personal and absolute idealism by emphasising the idea of the real as rational. For Gibson, the experience from which we start is personal, but it is also religious and spiritual. We must conceive the personal in relation to God. It is in this conception that absolute idealism and personal idealism would discover that they shared the view that the real is rational and spiritual (Boyce Gibson 1906-1907).

\section{Gibson's Views on Philosophy and Personality}

Although Gibson's early training had been in mathematics, it was a work on philosophy of religion that drove his conversion. The conversion took the form of grasping the difference between causal explanation in the sciences, which depends on an account of the 'totality of the relevant antecedent conditions', and the idea of 'final causation'. This distinction was driven home to him by the second of Edward Caird's Gifford Lectures on The Evolution of Religion, where Caird discussed 'Different Methods of Defining Religion'. In particular, Caird defined religion not by examining what is common to religions but through 'the differentiae of the highest forms' (Boyce Gibson 1904, pp. 190-191; Caird 1907, pp. 36-59).

For Gibson, 'the philosophical baptism, par excellence, is that which confers the grace of teleological insight'. This insight is quite distinct from the scientific, causal, and abstract view. To lose this sense of teleology is to lapse from philosophy into science (Boyce Gibson 1904, p. 192). He consistently upheld a distinction between philosophy and science, stressing that science was concerned with external nature, but that philosophy was concerned with experience, in particular the immediate knowledge that we are purposive. This intuition is an 'intuition of Ideals, Values and real possibilities' (Boyce Gibson 1933b, p. 93; Weigall 1919).

On Gibson's account, the essence of philosophy is reason which links the 'whole of our life and experience', found, for example, in 'art, religion, and statecraft', to the divine ideals of 'beauty, truth, and goodness'. Self-critical reason was fundamental to philosophy. Although at one point he had held out Hegel as providing the best definition of philosophy as self-criticism, Gibson's final works took Plato to be the exemplar of how philosophy is both argument and an aspiration for truth, in 
a 'complex unity of intuition, intellect, aspiration, and love'. Gibson shared the view of Samuel Alexander that philosophy should offer a 'vision of reality', and he stressed that philosophers should be judged not by their conception but 'by the comprehensiveness and rigour of the thought through which that insight is explored and driven home'. At an early stage, he had seen the contemporary role of philosophy as the search for a 'Monism of the right kind [sic], which shall do adequate logical justice to the moral claim of Personality to be free, and creative' (Boyce Gibson 1902-1903, p. 182; 1923, 1933c).

The fundamental argument that runs through much of Gibson's thought is that self-intuition is rational and concrete-it has rational content. In an article written before he commenced in Melbourne, Gibson pointed to thinkers, such as Descartes, Eucken, and Bergson, who shared the view that 'the experience of spiritual power is the fundamental fact with which philosophy has to reckon'. Modern psychology, particularly that of G. F. Stout, enabled this experience to be analysed 'as the central fact of life', traceable from an 'impression' through to experience, and into morality and religion (Boyce Gibson 1911-1912, pp. 87-88).

Following Stout, and with an eye on pragmatism, Gibson identified the impressions of our experience with purposive needs. These purposive needs embrace values as well as instincts, particularly the ideals of 'truth, beauty, and goodness'. 'The experience of power is in last resort the experience of the power of these ideals in the shaping and perfecting of life'. Towards the end of his life, Gibson reiterated that: 'The presence and efficacy of the Ideal is a feature, patent and palpable, of our very simplest and most ordinary experiences' (Boyce Gibson 1911-1912, p. 100; 1934, p. 40).

For Gibson, the self is a unification of experience in a spatio-temporal order. It is a 'non-rational' unity, which in fact applies to all life, although we become 'rational individuals' through the pursuit of our aspiration. The self is immediately aware of itself as self. It feels unity not as a unity of parts, but as a unity of 'total activity'; it is this 'total activity in which the self's conscious being consists'. Such experience is not to be 'proved' but to be 'grasped', and in grasping it we grasp our ends and ourselves as purposive agents (Boyce Gibson 1904, pp. 123-138; 1924, pp. 191-192).

Gibson was particularly critical of Kant for eliminating subjective experience in his account of the transcendental unity of apperception. He also criticised Kant for treating the category of cause as basic. He argued that Kant thereby eliminated the 'really [sic] subjective'. In Gibson's view, the objective presupposes the subjective, because objects are made intelligible in relation to subjective interest. For Gibson, 'Once you say [the] self [is] an object you've taken a step that defeats any attempt to develop a rational conception of experience' [sic] (Weigall 1919).

Although personal consciousness begins as 'psychic unification', it gains a more profound dimension through purposive striving. At the level of volition, personal consciousness becomes rational and derives its unity from the ideal. The ideal interpenetrates one's life, and 'self-development' fundamentally involves moving towards a deep unity of aspiration. 'Personality' involves the pursuit of an ideal good and should be contrasted with 'individuality', which Gibson saw as a merely formal notion. 
The notion of personality is not constrained by time or matter, and Gibson (like many personal idealists) subscribed to belief in immortality. Personality, as it develops through aspiration for the ideal, must persist. The ideal and the personal interpenetrate each other, although they do not submerge each other. For Gibson, the ideal exists as a super-personal being or 'supersoul'. Gibson's theory posited both the 'central supremacy' of God and 'the essential interests of man's free, inviolate personality’ (Boyce Gibson 1904, pp. 140-141,151-152, 220-223; 1925a). As with many idealists, however, the God of his philosophy is not immediately reconcilable with Christian doctrine.

Gibson approached all areas of philosophy from the perspective of immediate experience. In his first book, A Philosophical Introduction to Ethics (1904), he took as his key theme the idea that 'the individual's own inviolate spiritual experience' is 'the central fact in Moral Philosophy and in our human philosophy generally'. He identified a teleological 'spiritual principle' as 'the unifying agency in personal experience' and argued that personal idealism sought the ultimate reality in the only way it could be sought-'in and through our own personal experience'. As a monistic philosophy, personal idealism must seek self-consistency and system, and it must relate the self to the absolute. Personality must be distinguished from the absolute, because otherwise the reality and creativity of 'finite persons' would be sacrificed (Boyce Gibson 1904: v-vii, 58, 64-65).

In The Problem of Logic (first edition 1908), Gibson distinguished a number of phases of logic. 'Truth' was to be understood as unity, but his book dealt with logic as a search for the 'truth of fact'. He differentiated the 'propaedeutic' of logic- the theories of judgement, proposition, and formal logic-from logic as an account of scientific method. Gibson defined the 'unity of thought' in terms of the realm of fact relevant to the purposes of the thinker. He treated scientific method through an account of inference and evidence, where inductive method was also determined by the concept of 'relevant fact'. But whereas inductive method was of value in scientific thinking, in so far as it implied causal determinism it was relevant only to inorganic fact. Consciousness, on the other hand, implied teleology, and this put it beyond inductive explanation. Concepts such as 'freedom', 'immortality' and 'God' are beyond mechanical causation, and their logic is a philosophical, rather than inductive, logic (Boyce Gibson 1914, pp. 1,3-6,314,367,459-462). In a second volume, never produced, Gibson was to deal with 'Philosophical Logic', the inward meaning of 'truth', seen through a 'Personalistic Logic'.

With his emphasis on freedom and on personality as a psychological unity of aspiration, Gibson was profoundly indeterminist in relation to the moral and spiritual realm. This was encapsulated in the logical distinction he drew between scientific method and philosophy, where one is causal and the other teleological. We inhabit a world of real possibilities and effective actions. Our freedom of choice is real, and so is our freedom to create (Boyce Gibson 1925b).

In particular, Gibson argued that imagination is the foundation of volition, in that imagination establishes 'possibilities'. For Gibson, possibilities are 'real constituents of the volitional world'. Imagination, therefore, provided the psychological foundation for this realm of possibilities. Gibson suggested that it was necessary to 
recognise 'a negative and hypothetical moment in volition, the moment or phase which renders deliberation possible. It is only through such a phase that the natural situation can pass on into the spiritual'. At this moment, 'natural impulse' is 'arrested' and turned 'into a real possibility'. These real possibilities are intermediate between the 'non-volitional' and the 'positively volitional' and represent the foundation of ethics. The fully undetermined nature of the ethical means it can become either moral or immoral; it is a source of freedom and becomes moral or immoral as a result of the exercise of freedom (Boyce Gibson 1933b, pp. 4-6; 1935, pp. 16-18).

Although Gibson did not produce a completed system, his work was in the tradition of systemic philosophy, and he worked up his thought particularly through accounts of ethics, logic, spirituality, and value. That philosophy was, at its core, a philosophy seeking to ground itself in experience and articulated through a philosophical psychology. It was a philosophy which could be developed through a consistent form of criticism, relating concepts back to the content of immediate experience. Gibson did not, however, leave behind a school. Instead, he gave a rigorous account of one of the key themes in Australian intellectual life in the first half of the twentieth century - the concept of personality.

\section{Conclusion: The Decline of Idealism}

Looking back over a century since the inauguration of the first chair in philosophy at Melbourne in 1886, Miller's judgement (given earlier, section "Idealism in Australia") about the dominance of idealism in the early period of Australian philosophy seems sound. It is also clear that he was writing at a time when the idealist dominance was being challenged, most clearly in Sydney. Indeed, since the middle of the twentieth century, open avowals of idealism have been rare, and the term 'idealist' became something of a convenient label with which to dismiss vast tracts of philosophic thought.

One view of what happened to idealism is that it simply vanished, in Australasia as elsewhere, to be replaced by realism, pragmatism, Wittgensteinianism, or phenomenology. This is the view taken by Franklin: 'Absolute Idealism in its dayaround the $1890 \mathrm{~s}$ - became the first and only philosophy to be accepted as orthodoxy in the whole learned world (Paris, Heidelberg, Edinburgh, Peking, Adelaide. ..). Then it simply evaporated' (Franklin 2003, pp. 113-114). Franklin's account, though, puts the decline of idealism far too early-closer, in fact, to its modern origins than to its end. At the other end of the spectrum to Franklin, Michael Devitt half-seriously claimed in the 1980s that idealism still survived in Melbourne, reflecting the lack of sunshine compared to other Australian cities (Devitt 1984: vii).

A different view would be that idealism in Australasia declined at around the same time as in Britain. Idealism was in significant retreat in the British universities following the death of its great exponents such as Henry Jones in 1922, Bernard Bosanquet in 1923, and F. H. Bradley in 1924. Even before that, idealism was 
frequently criticised during the First World War for its connections with German thought. Much of its rhetoric seemed overbearing and out of place in the context of a new form of war and the international uncertainties that followed. Realism had experienced its own resurgence, led by thinkers such as Bertrand Russell and G. E. Moore. New approaches to philosophy began to attract attention, such as those of Wittgenstein and Husserl.

A generational change also occurred in Australasia. In New Zealand, the decline of idealism can be traced to 1931, when Dunlop was succeeded to the Chair at Otago by the British philosopher J. N. Findlay. Although having been a Hegelian, and later being responsible for a considerable revival of interest in Hegel, Findlay had been purged of all forms of idealism under the influence of Bertrand Russell. By the time he arrived in New Zealand, Findlay regarded it as his mission to 'introduce mathematical logic to the Antipodes' (Pigden 2007).

In Australia, Laurie had died, and Anderson and Mitchell had retired from their Chairs by the middle of the 1920s; W. R. Boyce Gibson retired in 1934. There was a dramatic changing of the philosophical guard when John Anderson arrived in Sydney. According to Anderson, there were no relations of ideas; no 'consciousness' nor conscious knowers; no normative values, judgements, nor feelings; no 'self' nor purpose nor God.

Moreover, there were no abstract entities of any sort, no entities over and above the spatio-temporal world. In social terms, he held the radical thesis that 'there is no such thing as the pure individual apart from society, any more than society apart from the individuals who compose it' (Anderson 1917). As James McAuley was to famously put it: 'John Anderson had an answer to every conceivable question. It was "No"' (Bogdan 1984, pp. 6-7). Gilbert Ryle was also reputedly to have said of Anderson that 'He thinks there are only brass tacks' (Honderich 1995, p. 58).

But generational change was not total. When, for example, Mitchell retired from the professorship in Adelaide in 1922, he was succeeded by John McKellar Stewart - the first Australian-born professor. He held the chair from 1923 to 1949 (Passmore 1963). McKellar Stewart brought with him familiar idealist themes such as in his early work on Bergson, viewed from the perspective of a Kantian conception of reason (McKellar Stewart 1911). He also published on psychological themes such as the 'unconscious' and the relation of psychology to ethics-viewing the issues through an idealist lens (McKellar Stewart 1923, 1926).

In a different sense, the disappearance of idealism was by no means complete. In Britain, for example, a new generation of philosophers, such as R. G. Collingwood and Michael Oakeshott, rejected the label 'idealism' but continued to develop a broadly idealist tradition. Their greatest influence was, however, often outside of philosophy departments, in history, art, and politics. In Australia, A. Boyce Gibson was frequently called an idealist, although he characterised himself as a kind of empiricist, but one who was 'wide of the type' (Boyce Gibson 1970, p. 101). He had clearly been influenced by idealism, in both absolute and personalist forms, and continued to use idealism as a point of reference. He died in 1972, having produced his major works only after his retirement (Helgeby 2008). 
Only in the 1980s did a significant reappraisal of British idealism begin, largely influenced by a perceived alignment between modern 'communitarian' social philosophy and the social and political ideas of Green and his successors. Similarly, but still more recently, it has been the social and political theory of Australian idealists that has kept their memory alive, and shown the relevance of idealism outside of the universities until at least the mid-century (Hughes-Warrington and Tregenza 2008; Melleuish 1995; Sawyer 2003). The emphasis on the social aspects of idealist thought brings out a key dimension to their theory and practice. Idealism had, however, in Australia as elsewhere, a far broader orientation. It is only through its metaphysical and moral dimensions that its social philosophy can be understood.

\section{References}

Acton, H. B. (1934). Review of 'the place of minds in the world. Gifford lectures at the University of Aberdeen 1924-26'. Mind, 63(170), 243-245.

Alexander, S. (1920). Space, time and deity. London: MacMillan.

Allen, H. J. (1984). Mitchell's concept of human freedom. Masters dissertation, University of Adelaide.

Anderson, F. (1902). A modern philosopher - Green of Balliol. In The Union Book of 1902... Being the Contribution of the Sydney University Union to the Celebration of the Jubilee of the University (1852-1902). Sydney: William Brooks pp. 175-197.

Anderson, F. (1922). Liberty, equality and fraternity. Sydney: Australasian Journal of Psychology and Philosophy, Monograph series, No. 1.

Anderson, F. (1923a). The present religious situation. Australasian Journal of Psychology and Philosophy, 1, 213-223.

Anderson, F. (1931a). The happy warrior. Australasian Journal of Psychology and Philosophy, 9, 263-268.

Anderson, F. (1931b). Sidelights I. On sidelights in general. Australasian Journal of Psychology and Philosophy, 9, 1-6.

Anderson, F. (1931c). Sidelights II. Gandhi contra mundum. Australasian Journal of Psychology and Philosophy, 9, 81-90.

Anderson, F. (1931d). Sidelights III. The simple life. Australasian Journal of Psychology and Philosophy, 9, 161-171.

Anderson, F. (1935). Peace or war. Sydney: Angus and Robertson.

Anderson, J. (1917). Is the State a Moral Agent? (Silver medal prize essay 1916-17). University of Glasgow Archives p. 45.

Anderson, J. (Ed.). (1980). Education and inquiry (Ed.: Phillips, D. Z.). Oxford: Blackwell.

Anderson, J. (2005). Space-time and the proposition: The 1944 lectures on Alexander's space, time and deity (Ed.: Weblin, M.). Sydney: Sydney University Press.

Anderson, J. (2007). Lectures on metaphysics 1949-1950: Space-time and the categories. Sydney: Sydney University Press.

Anderson, J., Cullum, G., \& Lycos, K. (1962). Studies in empirical philosophy. Sydney: Angus and Robertson.

Anderson, J., Cullum, G., \& Lycos, K. (Eds.). (1982). Art and reality: John Anderson on literature and aesthetics. Marrickville: Hale \& Iremonger.

Anderson, W. (1923b). The meaning of philosophy (II). Australasian Journal of Psychology and Philosophy, 1, 241-247.

Anderson, W. (1926). Psycho-biology and democracy - Human nature, science, and society. Australasian Journal of Psychology and Philosophy, 4, 41-56. 
Anderson, W. (1928). Self. Australasian Journal of Psychology and Philosophy, 6(2), 81-92.

Anderson, W. F. (1930a). On a University education. Australasian Journal of Psychology and Philosophy, 8, 241-246.

Anderson, W. (1930b). Individuality and community. Australasian Journal of Psychology and Philosophy, 8, 247-262.

Anderson, W. (1930c). On a fragment from Dewey. Australasian Journal of Psychology and Philosophy, 8, 168-175.

Anderson, W. (1934). Academic freedom. Australasian Journal of Psychology and Philosophy, $12,138-142$.

Anderson, W. (1938a). The entrance examination policy of the University of New Zealand (I). Australasian Journal of Psychology and Philosophy, 16, 23-40.

Anderson, W. (1938b). The entrance examination policy of the University of New Zealand (II). Australasian Journal of Psychology and Philosophy, 16, 143-172.

Anderson, W. (1944). The flight from reason in New Zealand education. Auckland: Catholic Teachers' Association.

Ardley, G. W. R. (1982). Sixty years of philosophy: A short history of the Auckland philosophy department 1921-1983 (2nd ed.). Auckland: Department of Philosophy, Auckland University.

Baker, A. J. (1979). Anderson's social philosophy. Hong Kong: Angus \& Robertson.

Baker, A. J. (1986). Australian realism: The systematic philosophy of John Anderson. Cambridge, UK: Cambridge University Press.

Beaglehole, E. (Ed.). (1946). The University \& the community: Essays in honour of Thomas Alexander Hunter. Wellington: Victoria University College.

Beaglehole, J. C. (1951). Sir Thomas Hunter. New Zealand Journal of Public Administration, 13, $1-5$.

Beaglehole, T. (2007). Hunter, Thomas Alexander 1876-1953: Vol.3. Dictionary of New Zealand Biography, 1901-1920. Wellington: Ministry for Culture and Heritage.

Bengtsonn, J. O. (2006). The worldview of personalism: Origins and early development. Oxford: Oxford University Press.

Blanshard, B. (1939). The nature of thought. London: George Allen \& Unwin.

Bogdan, R. J. (Ed.). (1984). D. M. Armstrong (Vol. 4). Dordrecht: Reidel.

Boucher, D. (1990). Practical Hegelianism: Henry Jones's lecture tour of Australia. Journal of the History of Ideas, 51, 423-452.

Boucher, D. (2004). The Scottish idealists: Selected philosophical writings. Exeter: Imprint Academic.

Boucher, D. (2005). Gibson, William Ralph Boyce (1869-1935). In S. Brown (Ed.), The dictionary of twentieth-century British philosophers (Vol. 1). Bristol: Thoemmes Continuum.

Boulger, Edward Vaughan, 1846-?. (1969). In Australian dictionary of biography (Vol. 3, p. 202). National Centre of Biography, Australian National University.

Boyce Gibson, A. (1932). The philosophy of Descartes. London: Methuen.

Boyce Gibson, A. (1937). Review of Henri Bergson's "The two sources of morality and religion". Australasian Journal of Psychology and Philosophy, 15, 65-80.

Boyce Gibson, A. (1938). Samuel Alexander: An appreciation. Australasian Journal of Psychology and Philosophy, 16, 251-254.

Boyce Gibson, A. (1964). Preface. In A. Boyce Gibson's Papers. Box 5/2/2/2, 74-17: University of Melbourne Archives.

Boyce Gibson, A. (1970). Theism and empiricism. London: SCM Press.

Boyce Gibson, W. (1933c). What is philosophy? Australasian Journal of Psychology and Philosophy, 6, 88-98.

Boyce Gibson, W. R. (1902-1903). The relation of logic to psychology with special reference to the views of Dr. Bosanquet. Proceedings of the Aristotelian Society, 3, 166-186.

Boyce Gibson, W. R. (1904). A philosophical introduction to ethics: An advocacy of the spiritual principle in ethics from a point of view of personal idealism. London: Swann Sonnenschein.

Boyce Gibson, W. R. (1906-1907). A peace policy for idealists. The Hibbert Journal, 5, 407-424. 
Boyce Gibson, W. R. (1907). Rudolf Eucken's philosophy of life. London: A. \& C. Black.

Boyce Gibson, W. R. (1911-1912). The experience of power. Proceedings of the Aristotelian Society, 12, 65-104.

Boyce Gibson, W. R. (1914). The problem of logic. London: A. \& C. Black.

Boyce Gibson, W. R. (1923). The meaning of philosophy (III). Australasian Journal of Philosophy and Psychology, 1, 248-255.

Boyce Gibson, W. R. (1924). Problems of spiritual experience: II. The personal bond. Australasian Journal of Philosophy and Psychology, 2, 183-196.

Boyce Gibson, W. R. (1925a). Does the ideal really exist? Australasian Journal of Philosophy and Psychology, 3, 159-178.

Boyce Gibson, W. R. (1925b). Problems of spiritual experience: IV. Freedom and evil. Australasian Journal of Philosophy and Psychology, 3, 91-98.

Boyce Gibson, W. R. (1928a). The philosophy of Melchior Palagyi. (I) space-time and the criticism of relativity. Journal of Philosophical Studies, 3, 15-28.

Boyce Gibson, W. R. (1928b). The philosophy of Melchior Palagyi. (II) the theory of life and mind. Journal of Philosophical Studies, 3, 158-172.

Boyce Gibson, W. R. (1933a). The ethics of Nicolai Hartmann. I. The Australasian Journal of Psychology and Philosophy, 11, 12-28.

Boyce Gibson, W. R. (1933b). Freedom and open responsibility. Paper presented on 29 September at the Symposium of Freedom and Responsibility. W. R. Boyce Gibson Papers, University of Melbourne Archives.

Boyce Gibson, W. R. (1934). The ethics of Nicolai Hartmann. II. Australasian Journal of Psychology and Philosophy, 12, 33-61.

Boyce Gibson, W. R. (1935). The ethics of Nicolai Hartmann. III. Australasian Journal of Psychology and Philosophy, 13, 1-23.

Brown, L. B., \& Fuchs, A. H. (1971). Early experimental psychology in New Zealand: The Hunter-Titchener letters. Journal of the History of the Behavioral Sciences, 7, 10-22.

Caird, E. (1907). The evolution of religion: The Gifford lectures delivered before the University of St. Andrews in sessions 1890-91 and 1891-92 (4th ed., 2 Vols., see Vol. 1). Glasgow: James Maclehouse.

Chalmers, D. (1996). The conscious mind. Cambridge: Cambridge University Press.

Churchland, P. M. (1979). Scientific realism and the plasticity of mind. New York: Cambridge University Press.

Churchland, P. M. (1986). Some reductive strategies in cognitive neurobiology. Mind, 95, 279-309.

Churchland, P. M. (1988). Perceptual plasticity and theoretical neutrality. Philosophy of Science, $55,167-187$.

Coleman, P. J. (1958). The spirit of New Zealand liberalism in the nineteenth century. The Journal of Modern History, 30, 227-235.

Collins, J. (2003). Criticisms and accommodations: The Thomas report and catholic secondary education in New Zealand. Paper presented at the NZARE/AARE Conference. http://publications.aare.edu.au/03pap/col03056.pdf

Coombs, A. (1996). Sex and anarchy: The life and death of the Sydney push. Ringwood: Viking.

Davies, W. M. (1999). Sir William Mitchell and the new mysterianism. Australasian Journal of Philosophy, 77, 253-257.

Davies, W. M. (2003). Philosophy of Sir William Mitchell (1961-1962): A mind's own place. Lewiston: Edwin Mellen Press.

Davies, W. M. (2004). Sir William Mitchell. Internet encyclopedia of philosophy. http://www.iep. utm.edu/m/mitchell.htm

Dennett, D. (1988). Quining qualia. In A. Marcel \& E. Bisiach (Eds.), Consciousness in contemporary science. Oxford: Oxford University Press.

Dennett, D. (1991). Consciousness explained. Boston: Little, Brown.

Devitt, M. (1984). Realism and truth. London: Basil Blackwell. 
Du Bois-Reymond, E. (1848). Animal electricity. London: Duckworth (Cited in Passmore J. A. (1985). Recent philosophers: A supplement to a hundred years of philosophy).

Duncan, W. G. K., \& Leonard, R. A. (1973). The University of Adelaide, 1874-1974. Adelaide: Rigby.

Dunlop, F. W. (1908). Deep love's severity and other sermons. Christchurch: Whitcombe \& Tombs.

Economics at Adelaide. (2003). Lumen Magazine. http://www.lumen.adelaide.edu.au/2003winter/ page15/

Edgeloe, V. (1993). Servants of distinction: Leadership in a young University 1874-1925. Adelaide: Educational Technology Unit, University of Adelaide Foundation.

Edgeloe, V. A. (1986). Mitchell, Sir William (1861-1962). In Australian dictionary of biography (Vol. 10, pp. 535-537). Melbourne: Melbourne University Press.

Egarr, T. (2006). Am I my brother's keeper? : State confinement in New Zealand under Dr. Duncan MacGregor and Capt. Arthur Hume, 1880-1910. BA (Hons.) thesis, University of Otago, Otago.

Eucken, R. (1909). Christianity and the new idealism: A study in the religious philosophy of to-day (trans: Gibson, L. J., Boyce Gibson, W. R.). London: Harper.

Flanagan, O. (1992). Consciousness reconsidered. Bradford: M.I.T Press.

Fletcher, M. S. (1912). The psychology of the new testament (2nd ed.). New York: Hodder \& Stoughton.

Franklin, J. (2003). Corrupting the youth: A history of philosophy in Australia. Sydney: Macleay Press.

Gardner, W. J., Beardsley, E. T., \& Carter, T. E. (1973). A history of the University of Canterbury, 1873-1973. Christchurch: University of Canterbury Press.

Gillett, C. (2006). Samuel Alexander's emergentism: Or higher causation for physicalists. Synthese, 153, 261-296.

Grave, S. A. (1976). Philosophy in Australia since 1958. Sydney: Sydney University Press.

Grave, S. A. (1981). Gibson, William Ralph Boyce. In Australian dictionary of biography (Vol. 8 , pp. 659-660). Melbourne: Melbourne University Press.

Grave, S. A. (1984). A history of philosophy in Australia. St Lucia: University of Queensland Press.

Gregory, H. (1987). Vivant professores: Distinguished members of the University of Queensland, 1910-1940. St. Lucia: University of Queensland Library.

Harvey, J. W. (1934). Review of 'the place of minds in the world: Gifford lectures at the University of Aberdeen 1924-26'. The British Institute of Philosophical Studies, 9, 103-106.

Helgeby, S. (2006). Personal idealism, criticism and system: The philosophy of William Ralph Boyce Gibson (1869-1935). Collingwood and British Idealism Studies, 12, 75-102.

Helgeby, S. (2008). Alexander Boyce Gibson: Theism, empiricism and idealism. Collingwood and British Idealism Studies, 14, 96-127.

Hetherington, H. J. W. (1924). The life and letters of Sir Henry Jones. London: Hodder \& Stoughton.

History of philosophy at the University of Canterbury. http://www.saps.canterbury.ac.nz/phil/ history.shtml

Hughenden History. (2006). http://www.thehughenden.com.au/about-us/hughenden-history/

Hoernlé, R. F. A. (1909). Critical notice of structure and growth of the mind. Mind, 18, 255-264.

Honderich, T. (Ed.). (1995). The Oxford companion to philosophy. Oxford: Oxford University Press.

Hughes-Warrington, M., \& Tregenza, I. (2008). State and civilisation in Australian new idealism, 1890-1950. History of Political Thought, 29, 89-108.

Hunter, T. A. (1924). What is wrong with the world? Australasian Journal of Psychology and Philosophy, 2, 51-57.

Hunter, T. A. (1927). Some concepts in relation to social science. Australasian Journal of Psychology and Philosophy, 5, 161-185. 
Hunter, T. A. (1928). Psychological clinic for children, Victoria University College, Wellington. Australasian Journal of Psychology and Philosophy, 6, 300-303.

Hunter, T. A. (1932). Some reflections on social institutions. Australasian Journal of Psychology and Philosophy, 10, 40-46.

Hunter, T. A. (1952). The development of psychology in New Zealand. Quarterly Bulletin of the British Psychological Society, 3, 101-111.

Huxley, T. H. (1874/1901). Of the hypothesis that animals are Automata, and its history, method and results. In Collected Essays: Vol. 1. Results and methods. New York: Appleton and Company.

Irons, D. (1899). Review of the origin and growth of the moral instinct. Philosophical Review, 8, $420-424$.

Jones, H. (1909). Idealism as a practical creed: Being the lectures on philosophy and modern life delivered before the University of Sydney. Glasgow: James Maclehouse \& Sons.

Kemp-Smith, N. (1908). Review of structure and growth of the mind. Philosophical Review, 17, 332-339.

Kennedy, B. (1995). A passion to oppose: John Anderson, philosopher. Carlton South: Melbourne University Press.

Kennett, P. (1991). Unsung hero: Barzillai Quaife. Palmerston North: Dunmore Press.

Laurie, H. (1881). A plea for philosophy. Victorian Review, 5, 76-89.

Laurie, H. (1885). The study of mental philosophy. The Melbourne Review, 38, 185-195.

Laurie, H. (1889). Some of Browning's thoughts about painting. An address delivered to Victorian artists. The Centennial Magazine, 2, 35-38.

Laurie, H. (1901). Some thoughts on immortality: A lecture. Melbourne: Melville and Muller.

Laurie, H. (1902). Scottish philosophy in its national development. Glasgow: J. Maclehose \& Sons.

Laurie, H. (1903). The theory of use-inheritance, psychologically considered. Paper presented at the report of the ninth meeting of the Australasian Association for the Advancement of Science, Hobart.

Laurie, H. (1908). Materialism. Paper presented at the report of the eleventh meeting of the Australasian Association for the Advancement of Science, Adelaide.

Laurie, H. (1912). Australian appreciation of Robert Browning. In W. A. Knight (Ed.), The Robert Browning centenary celebration at Westminster Abbey. Boston: Houghton Mifflin Company.

Laurie, H. (1921). Plato in English literature. A paper read before the Classical Association of Victoria, Carlton, Victoria.

Lockley, G. L. (1967). Barzillai Quaife (1798-1873). In Australian dictionary of biography (Vol. 2, pp. 356-357). Melbourne: Melbourne University Press.

Lovell, H. T. (1941). In memoriam. Francis Anderson, Challis professor of philosophy (1890-1921), University of Sydney. Australasian Journal of Psychology and Philosophy, 19, 97-101.

MacGregor, D. (1876, January). The problem of poverty in New Zealand. New Zealand Magazine, pp. 60-61.

MacGregor, D. (1897). Aspects of the charitable-aid question: Extracts from reports presented to the houses of the general assembly, New Zealand. Wellington: Government Printer.

Mackenzie, H. (1911). The origin and development of Priesthoods. National Register of Archives and Manuscripts, Victoria University.

Mackenzie, H. (1917a). Brief outline of the development of the English language. National Register of Archives and Manuscripts, Victoria University.

Mackenzie, H. (1917b). Utopias, ancient and modern. National Register of Archives and Manuscripts, Victoria University.

Mackenzie, H. (1921). Aspects of the philosophy of criticism (Aesthetics). National Register of Archives and Manuscripts, Victoria University.

Mackie, J. L. (1962). The philosophy of John Anderson. Australasian Journal of Philosophy, 40, 265-282. 
Masson, D. (1877). Recent British philosophy: A review, with criticisms: including some comments on Mr. Mill's answer to Sir William Hamilton (3rd ed.). London: MacMillan.

Matheson, P. (1993). Salmond, William 1835-1917. In Dictionary of New Zealand biography (Vol. 2, pp. 1870-1900). Wellington: Ministry for Culture and Heritage. www.teara.govt.nz/ en/biographies/2s3/1

McClelland, J. (1999). Cognitive modelling, connectionist. In R. A. Wilson \& F. C. Keil (Eds.), The MIT encyclopedia of the cognitive sciences. Cambridge: MIT Press.

McKellar Stewart, J. (1911). A critical exposition of Bergson's philosophy. London: MacMillan.

McKellar Stewart, J. (1923). The idea of the unconscious in the new psychology. Australasian Journal of Psychology and Philosophy, I, 191-197.

McKellar Stewart, J. (1926). The meeting-point of psychology and ethical theory. Australasian Journal of Psychology and Philosophy, IV, 77-90.

Melleuish, G. (1995). Cultural liberalism in Australia: A study in intellectual and cultural history. Cambridge: Cambridge University Press.

Merrylees, W. A. (1934). Descartes: An examination of some features of his metaphysics and methods. Melbourne: Melbourne University Press.

Merrylees, W. A. (1935). Obituary: William Ralph Boyce Gibson. Australasian Journal of Psychology and Philosophy, XIII, 85-92.

Miller, E. M. (1929). The beginnings of philosophy in Australia and the work of Henry Laurie, part 1. Australasian Journal of Psychology and Philosophy, 7, 241-251.

Miller, E. M. (1930). The beginnings of philosophy in Australia and the work of Henry Laurie, part II. Australasian Journal of Psychology and Philosophy, 8, 1-22.

Mitchell, W. (1895). Reform in education. International Journal of Ethics, 6, 24-50.

Mitchell, W. (1898). What is Poetry? A lecture given to the South Australian Teachers Union, Southern Cross Print.

Mitchell, W. (1903). Lectures on materialism. Extension lectures - Syllabus of three. Adelaide: Thomas.

Mitchell, W. (1907). Structure and growth of the mind. London: Macmillan.

Mitchell, W. (1912). Christianity and the industrial system. Adelaide: Hussey \& Gillingham. Issued by the Methodists Social Service League.

Mitchell, W. (1918, December 19). The national spirit. The Advertiser.

Mitchell, W. (1926). The power of the mind (Syllabus of the Gifford lectures, second series). Aberdeen: MacMillan.

Mitchell, W. (1929). Nature and feeling. Adelaide: Hassel \& Son Press.

Mitchell, W. (1933). The place of minds in the world. London: MacMillan.

Mitchell, W. (1934). The quality of life. In Proceedings of the British Academy, 20. Annual British Academy Henrietta Herz Lecture. Oxford: Oxford University Press.

Mitchell, W. (1937). Universities and life. Introductory address. Paper presented at the Australian and New Zealand Universities Conference, Adelaide.

Moon, P. (1997). Barzillai quaife: An early advocate of indigenous land rights in New Zealand and victim of censorship. Journal of Pacific History, 32, 234-242.

Mortensen, C. (2005). Review of the philosophy of Sir William Mitchell (1851-1962): A mind's own place. Australasian Journal of Philosophy, 83, 298-300.

Murray, N. S. (1944). The life and work of Dr. Duncan MacGregor. Otago: University of Otago.

Numbers, R. L., \& Stenhouse, J. (2000). Antievolutionism in the antipodes: From protesting evolution to promoting creationism in New Zealand. British Journal for the History of Science, $33,335-350$.

O’Neil, W. M. (1979). Anderson, Sir Francis (1858-1941). In Australian dictionary of biography (Vol. 7, pp. 53-55). Melbourne: Melbourne University Press.

Passmore, J. (1962). John Anderson and twentieth century philosophy. In J. Anderson (Ed.), Studies in empirical philosophy (pp. ix-xxiv). Sydney: Angus \& Robertson.

Passmore, J. (1963). Philosophy. In A. L. McLeod (Ed.), The pattern of Australian culture (pp. 131-169). Melbourne: Oxford University Press. 
Passmore, J. (1984). A hundred years of philosophy. London: Penguin.

Perry, R. B. (1908). Review of structure and growth of the mind. Journal of Philosophy, Psychology and Scientific Method, 5, 45-48.

Pigden, C. (2007). Philosophical history: The Otago Department. http://www.otago.ac.nz/philosophy/history.html

Quaife, B. (1845). A condensed view of the proper design and uses of the Lord's supper. Parramatta: Benjamin Isaacs.

Quaife, B. (1846). The rules of the final judgement: A sermon, the substance of which was preached at the Scots Church. Parramatta: Benjamin Isaacs.

Quaife, B. (1848). Lectures on prophecy and the kingdom of Christ. Sydney: Colman \& Piddington, \& W. Ford.

Quaife, B. (1872). The intellectual sciences. Sydney: Gibbs, Shallard and Co.

Roberts, J. (1997). Maybanke Anderson: Sex, suffrage and social reform (2nd ed.). Avalon: Ruskin Rowe Press.

Salmond, C. (1929). Some aspects of modern thought. Australasian Journal of Psychology and Philosophy, 7, 1-18.

Salmond, C. (1930). Psychological literature and human nature. Australasian Journal of Psychology and Philosophy, 8, 23-42.

Salmond, W. (1875). The Christian doctrine of providence and prayer and the reign of law: Three lectures. North Shields: John Shields.

Salmond, W. (1888). The reign of grace: A discussion of the question of the possibility of salvation for all men in this life, or in the life to come (3rd ed.). Otago: James Horsburgh.

Sawyer, M. (2003). The ethical state? Social liberalism in Australia. Melbourne: Melbourne University Press.

Smart, J. J. C. (1962). Sir William Mitchell K. C. M. G. (1861-1962). Australasian Journal of Philosophy, 40, 261-263.

Smart, J. J. C. (1990). Stewart, john McKellar (1878-1953). In Australian dictionary of biography (Vol. 12, p. 91). Melbourne: Melbourne University Press.

Smith, A. G. (1986). Laurie, Henry (1837-1922). In Australian dictionary of biography (Vol. 10, pp. 7-8). Melbourne: Melbourne University Press.

Stove, D. (1977). The force of intellect: Fifty years of John Anderson. Quadrant, 21, 45-46.

Sturt, H. (1902). Preface. In H. Sturt (Ed.), Personal idealism: Philosophical essays by eight members of the University of Oxford (pp. v-viii). London: MacMillan.

Sutherland, A. (1898). The origin and growth of the moral instinct. London: Longmans, Green.

Tennant, M. (1993). MacGregor, Duncan 1843-1906. Dictionary of New Zealand Biography (Vol. 2, pp. 1870-1900). Wellington: Ministry for Culture and Heritage. www.teara.govt.nz/en/ biographies//2m7/1

Tennant, M., \& Hanson, E. (1979). Social welfare: Social justice or social efficiency? Duncan MacGregor and charitable aid administration 1886-1896. New Zealand Journal of History, 13, $33-40$.

Thom, P. (2007). Philosopher kings. The philosopher's zone. http://www.abc.net.au/rn/ philosopherszone/stories/2007/2067525.htm\#transcript

Trahair, R. C. S. (1984). The humanist temper: The life and work of Elton Mayo. New Brunswick: Transaction Books.

van Gulick, R. (1993). Understanding the phenomenal mind: Are we all just Armadillos? In M. Davies \& G. W. Humphreys (Eds.), Consciousness: Psychological and philosophical essays. Oxford: Blackwell.

Walker, R. B. (1972). Davidson, John (1834-1881). In Australian dictionary of biography (Vol. 4, p. 26). Melbourne: Melbourne University Press.

Weigall, M. (1919). Honours metaphysics (Discussion class, Melbourne University). The University of Melbourne Archives, 88/24. 